\title{
Bargaining in the Shadow of the Law: The Case of Divorce*
}

\author{
Robert H. Mnookin ${ }^{\dagger}$ and Lewis Kornhauser $\ddagger$
}

This article suggests an alternative way of thinking about the role of law at the time of divorce. It is concerned primarily with the impact of the legal system on negotiations and bargaining that occur outside the courtroom. We see the primary function of contemporary divorce law not as imposing order from above, but rather as providing a framework within which divorcing couples can themselves determine their postdissolution rights and responsibilities. This process by which parties to a marriage are empowered to create their own legally enforceable commitments is a form of "private ordering."1

* Copyright 1979 by Robert H. Mnookin.

This article has its roots in collaborative research begun in 1976, when Professor Mnookin's research was supported by grants to the Childhood and Government Project from the Ford Foundation and the Carnegie Corporation of New York, and Professor Kornhauser was a graduate student in law and economics at Berkeley. Early drafts were presented at the Workshop in Law and Economics at the University of Chicago Law School, the Legal Theory Workshop at the Yale Law School, and at seminars at the University of California, Berkeley. The article was completed while Professor Mnookin was on sabbatical at the Centre for Socio-Legal Studies, Wolfson College, Oxford during the fall of 1978. He wishes to thank his colleagues at the Centre, especially John Eekelaar, for helpful comments and suggestions. On November 16, 1978, Professor Mnookin delivered the penultimate version of this article as a lecture at University College, London; this version will be published separately by him as part of that lecture series in Current Legal Problems. Many people made helpful comments and suggestions while this article evolved. Special thanks are owed to Robert Cooter, Melvin Eisenberg, Stephen Sugarman, Jan Vetter, and Michael Wald.

$\dagger$ Professor of Law, University of California, Berkeley.

$\mp$ Assistant Professor of Law, New York University School of Law.

1. Professors Hart and Sacks have written:

Every society necessarily assigns many kinds of questions to private decision, and then backs up the private decision, if it has been duly made, when and if it is challenged before officials. Thus, private persons are empowered, by observance of a prescribed procedure, to oblige themselves to carry out certain contractual undertakings, and, if dispute arises, to settle their differences for themselves. So may a host of other matters be settled which are immediately of private, but potentially of public, concern. In a genuine sense, these procedures of private decision, too, become institutionalized. An understanding of how they work is vital to an understanding of the institutional system as a whole.

H. Hart \& A. Sacks, The Legal Process: Basic Problems in the Making and Application of Law 7 (tent. ed. 1958). A definition of private ordering attributed to Professor Fuller is "law" that parties bring into existence by agreement. On the continuity between the social processes of negotiation and adjudication, see Eisenberg, Private Ordering Through Negotiation: Dispute-Settlement and Rulemaking, 89 HARv. L. REv. 637 (1976). 
Available evidence concerning how divorce proceedings actually work suggests that a reexamination from the perspective of private ordering is timely. "Typically, the parties do not go to court at all, until they have worked matters out and are ready for the rubber stamp."2 Both in the United States and in England, the overwhelming majority of divorcing couples resolve distributional questions concerning marital property, alimony, child support, and custody without bringing any contested issue to court for adjudication. ${ }^{3}$

This new perspective and the use of the term "private ordering" are not meant to suggest an absence of important social interests in how the process works or in the fairness of its outcomes. The implicit policy questions are ones of emphasis and degree: to what extent should the law permit and encourage divorcing couples to work out their own arrangements? Within what limits should parties be empowered to make their own law by private agreement? What procedural or substantive safeguards are necessary to protect various social interests?

Nor is this perspective meant to imply that law and the legal system are unimportant. To divorcing spouses and their children, family law is inescapably relevant. The legal system affects when a divorce may occur, how a divorce must be procured, and what the consequences of divorce will be. Our primary purpose is to develop a framework within which to consider how the rules and procedures used in court for adjudicating disputes affect the bargaining process that occurs between divorcing couples outside the courtroom. ${ }^{4}$

2. Friedman \& Percival, A Tale of Two Courts: Litigation in Alameda and San Benito Counties, 10 LAw \& Soc'Y REv. 267, 270 (1976). Friedman and Percival indicate that, in 1970, family law cases (primarily divorce and annulment) made up a high percentage of the civil caseloads in the trial courts of Alameda $(51.7 \%)$ and San Benito (61.7\%) Counties, California. See id. at 281-82. They conclude that in the vast majority of these family cases, as in other areas, the courts performed "routine administration" rather than dispute settlement through adjudication. Id. at 296. A study of divorce proceedings in Maryland nearly 50 years ago concluded, similarly, that extremely few cases involve an actual conflict; most are "formal contests waged simply to satisfy the demands of the judicial forms." 1 L. Marshall \& G. MaY, The Divorce Court 199 (1932); see 2 id. at 292 (1933) (Ohio) (four-fifths of divorce cases uncontested and "usually require but a few minutes" of court time).

3. Although there are no data that permit reliable estimates on a national basis, available estimates are that only a very small percentage of divorces-probably less than $10 \%-$ involve disputes that are contested in court. See M. Hunt, THE Wordd of THE FormerLy MaRRIEd 227 (1966); Galanter, Why the "Haves" Come Out Ahead: Speculations on the Limits of Legal Change, 9 LAw \& Soc'Y Rev. 95, 108 (1974). An English study found that custody or visitation was contested at a court hearing in only $6.9 \%$ of the cases involving minor children. J. Eekelaar \& E. Clive, Custody After Divorce 66 fFamily Law Studies No. 1, Centre for Socio-Legal Studies, Wolfson College, Oxford 1977).

4. In addition to affecting couples' bargaining behavior at the time of dissolution, divorce law may also influence a broad range of prior family decisions-e.g., when, whether, and whom to marry; the number, timing, and spacing of children; the allocation 
In this article we first examine the degree to which the law today authorizes private ordering at the time of divorce: to what extent can divorcing spouses create their own legally enforceable commitments? In this context, we will also explain why we think the legal system should provide divorcing couples broad power to resolve the various questions that arise. Second, we develop a simple bargaining model to suggest how the legal system affects negotiations between spouses and their representatives at the time of divorce. Finally, we apply this framework to several issues that have dominated much of the academic discussion concerning family law during recent years: (1) the advantages and disadvantages of discretion-conferring legal standards for child custody; (2) Goldstein, Freud, and Solnit's proposed visitation standard; (3) the role of lawyers in the divorce process; and (4) the role of courts in "undisputed" divorces.

\section{Private Ordering in Divorce}

\section{A. Existing Limits on Private Ordering}

A legal system might allow varying degrees of private ordering upon dissolution of the marriage. ${ }^{5}$ Until recently, divorce law at-

of resources during marriage; and whether and when to divorce. These effects, however, seem more speculative and remote. Many believe that people decide to marry and raise children without any consideration of the legal standards governing divorce dispositions. At any rate, given the present state of knowledge, both theoretical and empirical, concerning the effects of legal rules on behavior, this article does not attempt to trace out more general, longrun effects. An interesting comparison might be made with the growing discussion of the effect of economics on family decisions in, for example, Economics of THE FAMILY (T. Schultz ed. 1974).

5. The fact that a continuum exists can best be seen if one considers two extremes. At one extreme would be a society that prohibited married couples from determining for themselves the circumstances that permit divorce. The restriction could take the form of an absolute prohibition on divorce, or it might require an inquiry by a state official to determine whether narrowly defined "grounds" for divorce had been met. After a divorce, the state might assert a continuing regulatory power over child care and over transfers of resources between the spouses. At the opposite extreme would be a society that allowed a substantial degree of private ordering. Cf. R. Nozick, ANArchy, STATe, AND UtopI (1974) (discussing minimalist, "night-watchman" state). Marriage could be dissolved at the request of either spouse. A divorcing couple would then be free to make any mutually agreeable deal governing the division of their property, their respective child-rearing responsibilities, and their future economic claims on each other. The state would provide a court system to enforce this deal and to resolve any subsequent disputes. The state would also stand ready to impose a division of the couple's resources and responsibilities; but only if the spouses themselves were unable to reach a mutually acceptable bargain.

Between these two extremes lie a variety of intermediate measures by which the state can control or influence the process of dissolution. These measures can have varying degrees of intrusiveness on the power of the parties to strike their own bargain. For example, certain promises-e.g., never to request child support-might be made unenforceable. Certain minimum conditions-e.g., that each spouse receive a certain minimum 
tempted to restrict private ordering severely. Divorce was granted only after an official inquiry by a judge, who had to determine whether "appropriate grounds"-very narrowly defined in terms of marital offenses-existed. ${ }^{6}$ When a divorce was granted, the state asserted broad authority to structure the economic relationship of the spouses and to maintain regulatory jurisdiction over the children and their relationship to the parents. ${ }^{7}$ Doctrines such as collusion, ${ }^{8}$ connivance, ${ }^{9}$ and condonation ${ }^{10}$ were meant to curtail the degree to which parties themselves could bring about a divorce through agreement; the procedural requirements reflected the view that everyone was "a suspicious character."11 Obviously, the marital-offense regime could not, even at its most restrictive, eliminate collusion entirely. Some divorcing spouses worked things out for themselves and then (with their lawyers' help) staged a carefully rehearsed and jointly produced play for the court. ${ }^{12}$ Nevertheless, the legal system was structured to minimize private ordering.

Dramatic changes in divorce law during the past decade now permit a substantial degree of private ordering. The "no-fault revolution"13 has made divorce largely a matter of private concern. Parties

percentage of joint assets-might be required in any division of property. Or the state might require the parties to follow specified procedures-e.g., putting separation agreements in writing, obtaining prior official review, or observing a minimum waiting period.

6. See H. Clark, Domestic Relations 327-57 (1968) (describing grounds for divorce in marital-offense or fault-based regime). See generally H. O'GoRMAN, LAwYERS AND MATRImonial Cases (1963) (New York case study); M. Rheinstein, Marriage Stability, Divorce, AND THE LAw 28-50 (1972) (comparing liberal and conservative divorce laws); Note, The Administration of Divorce: A Philadelphia Study, 101 U. PA. L. Rev. 1204 (1953).

7. See generally Vernier \& Hurlbut, The Historical Background of Alimony Law and Its Present Statutory Structure, 6 LAw \& Contemp. Prob. 197, 201-11 (1939). Courts still retain broad power to determine the consequences of divorce with respect to child sup. port and custody.

8. See, e.g., Fuchs v. Fuchs, 64 N.Y.S.2d 487 (Sup. Ct. 1946) (party may reopen default judgment of divorce on ground that it was collusively obtained); Churchward v. Churchward, [1895] 64 L.J.P. (n.s.) 18 (1894); Puxon, Collusion (pts. I-2), 103 SoL. J. 686, 705 (1959).

9. See, e.g., Note, $A$ Survey of the Law of Condonation, Connivance and Collusion in New England, 35 B.U. L. REv. 99 (1955); Annot., 17 A.L.R.2d 342, 344 (1951) ("if one spouse corruptly consents to adultery committed by the other, he is not entitled to a divorce for that adultery"); Note, Connivance (series), 95 SoL. J. 147, 829 (1951).

10. See, e.g., Seiferth v. Seiferth, 132 So. $2 d 471$ (Fla. Dist. Ct. App. 1961); Tarr v. Tarr, 184 Va. 443, 447, 35 S.E.2d 401, 403 (1945) (voluntary cohabitation after knowledge of act of adultery is conclusive defense against divorce on that ground); Willan v. Willan, [1960] 2 All E.R. 463 (C.A.).

11. R. Jackson, The Machinery of Justice in England 55 (6th ed. 1972).

12. For a discussion of collusive divorces under the marital-offense regime, and the problems created for lawyers in that legal system, see 0 . MCGregor, Divorce IN ENGLAND 134-36 (1957); H. O'GoRMAN, supra note 6, at 20-35.

13. See generally M. WheELER, No-FAulT Divorce (1974) (discussing no-fault movement in United States). According to a recent survey, only three jurisdictions-Illinois, Pennsylvania, and South Dakota-retain only fault grounds for divorce. Freed \& Foster, Divorce in the Fifty States: An Outline, II FAM. L.Q. 297, 298 (1977). 
to a marriage can now explicitly create circumstances that will allow divorce. Indeed, agreement between spouses is not necessary in most states; either spouse can unilaterally create the grounds for dissolution simply by separation for a sufficient period of time. ${ }^{14}$

The parties' power to determine the consequences of divorce depends on the presence of children. When the divorcing couple has no children, the law generally recognizes the power of the parties upon separation or divorce to make their own arrangements concerning marital property and alimony. ${ }^{15} \mathrm{~A}$ spousal agreement may be subject to some sort of judicial proceeding-or, in England, submission to a Registrar-but on both sides of the Atlantic the official review appears to be largely perfunctory. ${ }^{16}$ In some American states a couple may make its agreement binding and final-i.e., not subject to later modification by a court. ${ }^{17}$

In families with minor children, existing law imposes substantial doctrinal constraints. For those allocational decisions that directly affect children-that is, child support, custody, and visitation-parents lack the formal power to make their own law. Judges, exercising

14. In 31 states divorce may be granted on the basis of an "irretrievable breakdown." Freed \& Foster, supra note 13 , at 300 . By moving out and consistently expressing an unwillingness to move back one spouse can, as a practical matter, produce an "irretrievable breakdown" even if the other spouse objects to a divorce. Twenty-one states permit divorce on the basis of separation for a specified period of time. Id. at 302.

15. See, e.g., ConN. GEN. STAT. $\$ \S 46 \mathrm{~b}-51(\mathrm{a})$, -66 (1979) (court shall enter decree when parties, not attorneys, execute written stipulation that irretrievable breakdown of marriage has occurred, appear in court, and submit agreement concerning alimony, property, and rights and obligations as to children, if any; agreement shall be incorporated into decree if, upon inquiry, court finds agreement fair and equitable); UNIFORM MARRIAGE AND DivoRCE ACT $\$ 306$ (adopted in five jurisdictions) (upon divorce, written separation agreement by parties concerning property will be set forth in decree of dissolution unless court finds agreement "unconscionable").

16. See C. Foote, R. Levy \& F. Sander, Cases and Materials on Family Law 904 (2d ed. 1976) ("Only rarely do the courts interfere with the agreement worked out by the parties."); W. Baker, J. Eekelaar, C. Gibson \& S. Raikes, The Matrimonial Jurisdiction of Registrars 58 (Family Law Studies No. 2, Centre for Socio-Legal Studies, Wolfson College, Oxford 1977) (empirical study reporting that in England "it is the practice in consent applications not to require any information in addition to that presented to the court, even if the file contains no information at all") [hereinafter cited as Registrars Study]; id. at 59 (commonly registrar "would investigate only if something was obviously wrong," at least when no children were involved). Appellate courts, however, sometimes urge more intensive review. See Monroe v. Monroe, 40 Conn. L.J. 14, 17 (Sup. Ct. Mar. 27, 1979) (criticizing trial referee's failure "to ascertain the parties' actual consent to the proposal before him. Because of the emotionally-laden circumstances under which negotiations about marital dissolutions necessarily take place, reasonable inquiries should be made to ensure . . . that reasonable settlements have been knowingly agreed upon.") (footnote omitted).

17. See, e.g., GaL. Civ. Code $\$ 4811$ (b) (West Supp. 1979) (alimony); Conn. Gen. Stat. $\$ \$ 46 \mathrm{~b}-5 \mathrm{l}(\mathrm{a}),-66,-86$ (1979) (alimony and property); UNIFORM MARRIAGE AND Divorce AcT $\$ 306(f)$ (adopted in 5 jurisdictions) (property). 
the state's parens patriae power, are said to have responsibility to determine who should have custody and on what conditions. ${ }^{18}$ Private agreements concerning these matters are possible and common, but agreements cannot bind the court, ${ }^{19}$ which, as a matter of official dogma, is said to have an independent responsibility for determining what arrangement best serves the child's welfare. ${ }^{20}$ Thus, the court has the power to reject a parental agreement and order some other level of child support or some other custodial arrangement it believes to be more desirable. Moreover, even if the parties' initial agreement is accepted by the court, it lacks finality. A court may at any time during the child's minority reopen and modify the initial decree in light of any subsequent change in circumstances. ${ }^{21}$ The parties entirely lack the power to deprive the court of this jurisdiction.

On the other hand, available evidence on how the legal system processes undisputed divorce cases involving minor children suggests that parents actually have broad powers to make their own deals. Typically, separation agreements are rubber stamped even in cases involving children. A study of custody in England suggests, for example, that courts rarely set aside an arrangement acceptable to the parents. ${ }^{22}$ Anecdotal evidence in America suggests that the same is true here. ${ }^{23}$

The parents' broad discretion is not surprising for several reasons. First, getting information is difficult when there is no dispute. The state usually has very limited resources for a thorough and independent investigation of the family's circumstances. Furthermore, parents may be unwilling to provide damaging information that may upset their agreed arrangements. Second, the applicable legal standards are extremely vague and give judges very little guidance as

18. See, e.g., Leigh v. Aiken, 54 Ala. App. 620, 623, 311 So. 2d 444, 447 (1975); Sheets v. Sheets, 22 A.D.2d 176, 178, 254 N.Y.S.2d 320, 323 (1964).

19. See, e.g., Uniform Marriage and Divorce Act $\$ 306(\mathrm{f})$ (enacted in five jurisdictions).

20. See, e.g., Stewart v. Stewart, 130 Cal. App. 2d 186, 193, 278 P.2d 441, 445 (1955) (parental contract as to custody is "binding upon them," but cannot interfere with "that wide discretionary power given to courts in the disposition of the custody of children, in accord with their best interests, or independently of the desire of a parent"); Kritzik v. Kritzik, 21 Wis. 2d 442, 448, 124 N.W.2d 581, 585 (1963).

21. See H. Clark, supra note 6, at 498-99, 598-99 (child support and custody); $R$. Mnookin, Child, Family and State 197 (1978) (child support).

22. The study found that, in uncontested divorce cases involving children, the court adjourned for further information or negotiation in less than $10 \%$ of cases; that a welfare report was available in only $8.2 \%$ of uncontested cases; and that the courts changed the child's residence in only $0.6 \%$ of uncontested cases. J. Eekelaar \& E. Clive, supra note 3 , at 65-66.

23. See J. Despert, Children of Divorce 189 (1953) (ABA report in 1948 that $85 \%$ of divorced parents reach agreement on custody); Hansen, The Role and Rights of Children in Divorce Actions, 6 J. FAM. L. 1, 2 (1966) (90\%). 
to what circumstances justify overriding a parental decision. ${ }^{24}$ Finally, there are obvious limitations on a court's practical power to control the parents once they leave the courtroom. For all these reasons, it is not surprising that most courts behave as if their function in the divorce process is dispute settlement, not child protection. ${ }^{25}$ When there is no dispute, busy judges or registrars are typically quite willing to rubber stamp a private agreement, in order to conserve resources for disputed cases. ${ }^{26}$

\section{B. The Advantages of Private Ordering}

Before proceeding further, we should make clear the reasons why we think the law should give divorcing spouses broad powers to make their own agreement. There are obvious and substantial savings when a couple can resolve distributional consequences of divorce without resort to courtroom adjudication. The financial cost of litigation, both private and public, is minimized. The pain of a formal adversary proceeding is avoided. Recent psychological studies indicate that children benefit when parents agree on custodial arrangements. ${ }^{27}$ Moreover, a negotiated agreement allows the parties to avoid the risks and uncertainties of litigation, which may involve all-or-nothing consequences. Given the substantial delays that often characterize contested judicial proceedings, ${ }^{28}$ agreement can often save time and allow each spouse to proceed with his or her life. Finally, a consensual solution is by definition more likely to be consistent with the pref-

24. See Foster \& Freed, Child Custody (pt. 1), 39 N.Y.U. L. REv. 423, 423 (1964); Mnookin, Child-Custody Adjudication: Judicial Functions in the Face of Indeterminacy, LAw \& Contemp. Prob., Summer 1975, at 226, 249-54; Oster, Custody Proceeding: A Study of Vague and Indeterminate Standards, 5 J. FAM. L. 21, 23-25 (1965).

25. See Mnookin, supra note 24 , at 229 (in custody, dispute settlement involves "[choosing] between two or more private individuals, each of whom claims an associational interest with the child"; child protection "involves the judicial enforcement of standards of parental behavior believed necessary to protect the child").

26. R. MNookin, supra note 21, at 628. A study of Connecticut courts revealed that the average amount of time for a court hearing on an uncontested divorce was four minutes. Project, The Unauthorized Practice of Law and Pro Se Divorce: An Empirical Analysis, 86 YaLe L.J. 104, 127 (1976) [hereinafter cited as Pro Se Divorce].

27. See Note, Lawyering for the Child: Principles of Representation in Custody and Visitation Disputes Arising from Divorce, 87 YALE L.J. 1126, 1131 -32 \& nn.19-24 (1978) (citing sources) [hereinafter cited as Lawyering for the Child].

28. In Connecticut and New Jersey, for example, an uncontested divorce case can be immediately scheduled for hearing as soon as statutory waiting periods have passed and processing by the court administrators has been completed. Contested cases, however, generally wait at least a year from the time the parties are ready until a trial date can be scheduled. Telephone Interview with Hon. Robert Berdon, Judge, Connecticut Superior Court (Mar. 28, 1979); Telephone Interview with Hon. Harvey R. Sorkow, Presiding Judge, Matrimonial Division (temporarily assigned), Superior Court of New Jersey, Bergen County (Mar. 28, 1979) (Bergen County only). 
erences of each spouse, and acceptable over time, than would a result imposed by a court.

In divorces that involve no minor children, divorcing couples should have very broad powers to make their own arrangements; significant limitations are inconsistent with the premises of no-fault divorce. After all, who can better evaluate the comparative advantages of alternative arrangements than the parties themselves? ${ }^{29}$ Courts should not, of course, enforce agreements that reflect fraud or overreaching. Nor do we wish to minimize the importance of appropriate standards for alimony and marital property, for, as will be discussed, these standards very much affect negotiated outcomes..$^{30}$ Nonetheless, against a backdrop of fair standards, parties should be encouraged to settle these economic issues for themselves. The state should provide an efficient and fair mechanism for enforcing such agreements and for settling disputes when the parties are unable to agree.

When there are minor children, the state obviously has broader interests than simple dispute settlement. The state also has a responsibility for child protection. ${ }^{31}$ To acknowledge this responsibility, however, is not to define its limits. Indeed, the critical questions concern the proper scope of the child-protection function at the time of divorce and the mechanisms that best perform this function.

For reasons one of us has spelled out at length elsewhere, the actual determination of what is in fact in a child's best interest is ordinarily quite indeterminate. ${ }^{32}$ It requires predictions beyond the capacity of the behavioral sciences ${ }^{33}$ and involves imposition of values about which there is little consensus in our society. ${ }^{34}$ Thus, the fundamental question is: who gets to decide on behalf of the child? To what extent should the child's parents be given the freedom to decide between themselves how responsibility for their children is to be allocated following divorce?

We believe divorcing parents should be given considerable freedom to decide custody matters-subject only to the same minimum standards for protecting the child from neglect and abuse that the state imposes on all families. A negotiated resolution is desirable from the child's

29. Each spouse, in the words of John Stuart Mill, "is the person most interested in his own well-being: . . . with respect to his own feelings and circumstances, the most ordinary man or woman has means of knowledge immeasurably surpassing those that can be possessed by any one else." J.S. Mili, On Liberty, in ON LiberTy and RePresentative GovernMENT 68 (R. McCallum ed. 1947) (1st ed. London 1859).

30. See pp. 968-70 infra.

31. Mnookin, stupra note 24, at 229, 232.

32. Id. at 255.62.

33. Id. at 258-60.

34. Id. at $260-61$. 
perspective for several reasons. First, a child's social and psychological relationships with both parents ordinarily continue after the divorce. A process that leads to agreement between the parents is preferable to one that necessarily has a winner and a loser. A child's future relationship with each of his parents is better ensured and his existing relationship less damaged by a negotiated settlement than by one imposed by a court after an adversary proceeding. Notions of child protection hardly justify general judicial suspicion of parental agreements; the state's interest in the child's well-being in fact implies a concomitant interest in facilitating parental agreement.

Second, the parents will know more about the child than will the judge, since they have better access to information about the child's circumstances and desires. Indeed, a custody decision privately negotiated by those who will be responsible for care after the divorce seems much more likely than a judicial decision to match the parents' capacities and desires with the child's needs.

If parents have the authority to decide custodial arrangements, there is no doubt that parents may make mistakes. But so may judges. More fundamentally, given the epistemological problems inherent in knowing what is best for a child, there is reason to doubt our capacity to know whether any given decision is a mistake. Therefore, the possibility that negotiated agreements may not be optimal for the child hardly can be a sufficient argument against a preference for private ordering. Moreover, because parents, not state officials, are primarily responsible for the day-to-day child-rearing decisions both before and after divorce, parents, not judges, should have primary authority to agree on custodial arrangements. This means that courts should not second-guess parental agreements unless judicial intervention is required by the narrow child-protection standard implicit in neglect laws. ${ }^{35}$ This is not to suggest that the state does not have an important responsibility to inform parents concerning the child's needs during and after divorce; nor does it mean that the state does not have an important interest in facilitating parental agreement. Nevertheless, the law in action, which acknowledges substantial parental power, seems preferable to existing doctrine, which imposes substantial restrictions on the parents' power to decide for themselves.

35. See id. at 282.

For two articles emphasizing the importance of parental decisions, see Kubie, Provisions for the Care of Children of Divorced Parents: A New Legal Instrument, 73 YaLE L.J. 1197 (1964); Spencer \& Zammit, Mediation-Arbitration: A Proposal for Private Resolution of Disputes Between Divorced or Separated Spouses, 1976 DUKE L.J. 911. 


\section{The Elements of a Bargaining Model}

Whether or not one accepts the desirability of private ordering, it is clear that most divorcing couples do not require adjudication of their disputes. It is therefore appropriate to analyze how the legal system affects the bargaining behavior of divorcing couples.

\section{A. Doctrinal Divisions from a Bargaining Perspective}

Legal doctrine separates the potential consequences of divorce into four distributional questions: (l) how should the couple's property -the stock of existing wealth owned separately or together-be divided? (marital property law); (2) what ongoing claims should each spouse have on the future earnings of the other? (alimony law); (3) what ongoing claims should a child have for a share of the earnings or wealth of each of his parents? (child-support law); and (4) how should the responsibilities and opportunities of child rearing be divided in the future? (child-custody and visitation law).

These four strands of law, and the procedural mechanisms for their implementation, are conventionally seen by legal commentators from a highly regulatory perspective. Analysis seems premised on the notion that the distributional consequences of divorce should be determined through judicial or administrative proceedings in which legal standards are imposed from above on the divorcing spouses. ${ }^{36}$ Moreover, it is generally assumed that the doctrinal boundaries between these four issues are clear. ${ }^{37}$

Reexamination from the perspective of spouses who are negotiating their own settlements suggests three important conclusions. First, marital property, alimony, and child-support issues are all basically problems of money, and the distinctions among them become very blurred. Each can be translated into present dollar values. Although there are differences among the three with respect to termination and enforcement risks, the value of different bundles of the three

36. Professor Clark's hornbook on domestic relations, for example, devotes seven chap. ters (over 300 pages) to divorce, alimony and property-division, child-support, and custody issues. Only one chapter deals with separation agreements, and it emphasizes problems of judicial enforcement and construction rather than the influence of the rules on bargains. See H. Clark, supra note 6, at 280-601. Law review articles in this field typically focus on questions of the rules and procedures courts do or should employ in adjudication, and they largely ignore the effect of the rules and standards on negotiations outside of the courtroom.

37. Commentators typically discuss, for example, each doctrinal strand without acknowledgment of its relationship to the others. See, e.g., Symposium, The Uniform Marriage and Divorce Act: Strengths, Weaknesses, Alternatives, 18 S.D. L. REv. 531 (1973). But see Watson, The Children of Armageddon: Problems of Custody Following Divorce, 21 Syracuse L. Rev. 55, 59 (1969) (noting link between custody and money issues). 
elements can be compared. Second, custodial arrangements can often be divided in a wide variety of ways. Third, the money and custody issues are inextricably linked.

\section{The Money Elements of the Bargain}

\section{a. Alimony and Child Support}

From the economic perspective of bargaining spouses, alimony and child support seem fungible: both involve periodic money payments and, indeed, will often be paid by a single check from the noncustodial parent. A father may find it psychologically easier to pay child support, which will presumably only help his children, than alimony, which explicitly helps his former spouse. ${ }^{38}$ But this characterization hardly imposes much of a practical constraint. A custodial spouse is not required to keep track of how child-support money is spent, and the courts do not supervise child-support expenditures once a payment has been made. Even if a court were concerned with how transfer payments are spent, accounting would be extremely difficult. Many tangible goods and services in a family setting have some element of "joint consumption." 39 For example, the custodial spouse and the child will generally share housing. This makes it impossible to provide high-quality housing for the child without also providing it for the custodial spouse. Similarly, it would be difficult and expensive to provide the custodian and child with different diets and different social milieux. Consequently, child-support payments that are used for housing and feeding the child will inevitably inure to the benefit of the custodial spouse.

Joint consumption may also create a normative dilemma with respect to alimony and child-support standards. Divorce or separation typically occasions an economic loss that must be borne by someone. ${ }^{40}$

38. See Registrars Study, supra note 16, at 32 (English study found fathers more willing to pay child support than alimony).

39. On joint consumption, see J. Head, Public Goons and Public Welfare 77-80, 167 . 69, 176-79 (1974); J. Henderson \& R. Quand, Microeconomic Theory 270.72 (2d ed. 1971); E. Malinvaud, Lecturfs on Microeconomic Theory 211-18 (1972).

40. An economic loss arises because separation or divorce typically causes the loss of certain economies of scale that are common within a household. Housing for four people living together in a single household will often cost less than the same quality of housing for two separate households composed of a single individual and three persons respectively. Economies of scale may also arise because of medical and auto insurance costs. Furthermore, some durable goods (washing machines, freezers, etc.) may come in sizes that are too large for a single user. Parents may easily share one car until dissolution. After the divorce, two cars may become necessary, or one parent may be forced to use public transportation. 
Our legal and cultural norms reflect the notion that children should not bear the economic loss, ${ }^{41}$ and that, other things being equal, the spouses should bear the loss equally. ${ }^{42}$ Because joint consumption implies that the custodial parent and children must essentially share the same standard of living, a dilemma arises: either the children must bear some part of the economic loss, or the noncustodial parent must bear much more of the extra financial burdens imposed by divorce than the custodial spouse. ${ }^{43}$

Financial provision for a spouse terminates automatically on remarriage or death, while child-support normally ends when a child reaches his majority or is emancipated.44 The parents will know how many years remain before a child will reach majority; however, there may be considerable uncertainty about the probability that a spouse who is receiving alimony will remarry. Therefore, the characterization of the elements of payments will probably affect a party's calculation of the risks concerning how long a payment will last and

41. The goal has been to set child support at a level allowing the children " 'to be brought up with as nearly as possible the same standard of opportunity as they would have enjoyed had the marriage not failed.'" R. LEVY, UNIFORM MARRIAGE AND DIVORCE Legislation: A Preliminary Analysis 205 (undated) (quoting Putting Asunder: A Divorce LAW FOR CONTEMPORARY SOCIETY (report of group appointed by Archbishop of Canterbury to study reform of divorce law, Jan. 1964)); see H. Crark, supra note 6, at 496 " Within the limits of the husband's means, the child is entitled to an adequate provision for his needs, one which reflects the income level and scale of living of the family before the divorce."); cf. Commonwealth ex rel. Kaplan v. Kaplan, 236 Pa. Super. Ct. 26, 28, 344 A.2d 578, 579 (1975) (stating as "blackletter" law principle that "responsibility of the parents, to support the child to the best of their ability, consistent with their own station in life, is "well nigh absolute" "); UNIForm MARRLaGe and Divorce AcT $\S 309(3)$ (enacted in five jurisdictions) (prescribing as one relevant factor in determination of appropriate child-support payments "the standard of living the child would have enjoyed had the marriage not been dissolved").

42. The husband and wife now occupy a position of equal partners. Whether the marriage continues or is severed, the woman is as fully equipped as the man to earn a living. The husband and wife share equal rights and obligations in the marriage relationship and share equal burdens in the event the marriage is dissolved.

Spotts v. Spotts, 355 So. 2d 228, 230 (Fla. Dist. Ct. App.), cert. denied, 361 So. 2d 835 (Fla. 1978); cf. Orr v. Orr, 47 U.S.L.W. 4224 (U.S. Mar. 5, 1979) (statutory scheme imposing alimony obligation on husbands but not wives violates equal protection clause).

43. Professor Areen suggests that the economic allocation between spouses at divorce can be seen as governed by one of five conflicting principles: the fault principle, the need principle, the rehabilitation principle, the status principle, and the contribution principle. J. AREEN, FAMILY LAw 634-35 (1978). With the exception of the status principle-which would require spousal support at a level permitting the custodial parent to maintain his or her prior economic status-each of the other principles said to underlie alimony is different from the governing principle for child support. Consequently, to the extent there is joint consumption, the dilemma would exist.

44. Some statutes provide for automatic termination of alimony upon remarriage unless the parties provide otherwise; absent a statute, remarriage provides grounds for modification. See H. Clakk, supra note 6, at 457-59. On child support, see R. MNookIN, supra note 21, at 192. 
how easily it can be modified in the future. The characterization of the elements may also affect the tax consequences. ${ }^{45}$ However, the tax laws give divorcing spouses broad power to control by their own agreement the characterization, and hence tax consequences, of support payments. ${ }^{46}$ Presumably, each spouse is only interested in the risk-adjusted flow of his or her net income after taxes, taking into account the receipt or payment of interspousal money transfers. Thus, to the extent that the different consequences of alternative legal characterizations can be known and evaluated in advance, alimony and child support remain largely fungible for bargaining purposes.

\section{b. Lump-Sum Payments versus Payments over Time}

From a bargaining perspective, the more important distinction will be between a lump-sum transfer of money or property, which is typical of marital property, and payments over time, whether alimony, child support, or a combination of the two. Inflation aside, receiving $\$ 100$ today is preferable for several reasons to receiving a promise of $\$ 10$ each year for ten years. First, the present value of any stream of future payments must reflect a discount for the fact that the total amount is unavailable to invest or spend during the entire ten-year period. Second, when a recipient is receiving money over time, he or she faces the risk that the promise may be broken, or may be enforceable only at considerable expense. ${ }^{47}$ Periodic alimony or child-support payments thus pose risks of noncollection that are avoided by a lump-sum settlement. Finally, lump-sum and periodic transfers are taxed differently under the Internal Revenue Code.48

Despite these important differences, it would not seem especially difficult during bargaining to convert lump-sum offers into offers involving flows over time. For any set of time preferences, one spouse can in principle convert a money flow over time into a present-value equivalent. ${ }^{49}$ Moreover, a recipient can always discount the value of

45. Alimony is deductible from the income of the payor and is included in the income of the recipient, while child support is not deductible by the payor, and is not included in the income of the custodial spouse or the child. See I.R.C. $\$ \S 71,215$.

46. See Commissioner v. Lester, 366 U.S. 299 (1961).

47. See generally R. MNookun, supra note 21, at 200-03 (discussing problems of enforcing child-support obligations). The risk of nonpayment is substantial. Evidence suggests that many fathers fail to make child-support and alimony payments after divorce. See Chambers, Men Who Know They Are Watched: Some Benefits and Costs of Jailing for Nonpayment of Support, 75 Mich. L. Rev. 900, 904-27 (1977).

48. See I.R.C. $\$ 71(c)$. Lump-sum property settlements, unlike alimony, are not included in the taxable income of the recipient. See id. $\$ 71(\mathrm{~d})$.

49. See generally J. Hirshleifer, InVEstment, INTERest and Capital $31-45$ (1970) (discussing intertemporal choice). Obviously the two spouses may have different time preferences, and as a consequence apply different discount rates. 
a promise to reflect the perceived risks that the full amount may never be received. Finally, the tax consequences of alternatives can be evaluated and compared.

This ability to compare different packages has obvious implications for private bargaining, at least when the couple has sufficient economic resources. Sophisticated parties and their lawyers will attempt to seek out circumstances in which a different characterization, because of tax effects or differences in risk or time preferences of the parties, can make both spouses better off. ${ }^{50}$

\section{Custody}

The remaining element of the bargain concerns the custodial duties and rights of the parents. By varying the time the child spends with each parent, and by assigning particular child-rearing tasks to one parent or the other, a divorce settlement may divide prerogatives in many different ways. At the extreme, one parent may be entirely responsible for the child all the time, with the other spouse spending no time with the child. Or, divorcing parents may agree to share child-rearing responsibilities equally after divorce through joint custody ${ }^{51}$ For example, the child may live with each parent one-half of the time, with the parents together deciding where and how the child should be educated, who the pediatrician should be, etc. Between these extremes, many other alternatives are often possible.

\section{The Relationship of Custody and Money}

The preceding analysis suggests that, to a considerable degree, it is possible to reduce the concerns of divorce bargaining into two elements: money and custody. ${ }^{52}$ From a bargaining perspective, even

50. The fungible nature of the money elements can be seen from a simple example. Suppose the only asset that divorcing spouses own is a car worth $\$ 10,000$. The parties agree that each is entitled to one-half the value, and that one of them (let us assume the husband) wants to keep the car after divorce. Obviously he could simply pay his wife $\$ 5,000$ at the time of divorce for her share of the marital property. Alternatively, he might offer her periodic payments. Presumably the wife would not accept his offer of $\$ 500$-a-year alimony for 10 years as equivalent to $\$ 5,000$ at the time of divorce. Such an offer would not reflect the time value of money, a premium for the risk to the wife that the husband might not pay in the future, or the differences in tax consequences. On the other hand, there might be some periodic payment-say $\$ 2,000$ a year for three yearsthat the wife would prefer to a lump-sum payment of $\$ 5,000$. If the parties have different time preferences (and hence discount rates) there may be a set of periodic payments that both spouses prefer to a given lump-sum transfer.

51. See M. Roman \& W. Haddad, The Disposable Parent 173-77 (1978) (calling for statutory or, in its absence, common law presumption of joint custody).

52. Although in what follows, we summarize the concerns of the divorcing spouses in terms of "money" and "custody," the analysis does not rest on there being only two elements of exchange. Alimony, child support, and marital property could be treated as 
these two elements are inextricably linked for two reasons: over some range of alternatives, each parent may be willing to exchange custodial rights and obligations for income or wealth, and parents may tie support duties to custodial prerogatives as a means of enforcing their rights without resort to court.

Economic analysis suggests that a parent may, over some range, trade custodial rights for money. Although this notion may offend some, a contrary assertion would mean that a parent with full custody would accept no sum of money in exchange for slightly less custody, even if the parent were extremely poor. Faced with such alternatives, most parents would prefer to see the child a bit less and be able to give the child better housing, more food, more education, better health care, and some luxuries. Suggesting the possibility of such trade-offs does not mean that the parent would be willing to relinquish all time with the child for a sufficiently large sum of money. Indeed, with a minimum level of resources, a parent may have a parallel minimum of custodial rights for the reduction of which no additional payment, however large, could be adequate compensation.

The negotiating process itself provides many opportunities for the parties to link money and custody issues. The most obvious opportunity exists in the context of enforcement of support or visitation. The legal system does not permit these connections in most states: in a suit brought to collect overdue support payments, a father cannot defend on the ground that his ex-wife did not permit visitation. ${ }^{53}$ Nor have courts permitted a custodial parent to cut off visitation because of a failure to pay support. ${ }^{54}$ Nevertheless, it is often time-

different commodities. The bargain analysis would still apply because these commodities are substitutes for each other and represent different forms that money transfers can take. We have identified four dimensions along which alimony, child support, and marital property transfers may differ: (1) time flow; (2) tax conseqences; (3) risks of nonpayment; and (4) enforcement characteristics. Along each of these dimensions, every combination of property, alimony, and child support might be rated. Our use of money as an index for all three suggests simply that any combination can be reduced to a single valuation number.

53. See, e.g., In re Dooley, 30 Or. App. 989, 569 P.2d 627 (1977) (custodial parent's interference with visitation not in itself change of circumstances warranting reduction or elimination of child support); H. CLARK, supra note 6, at $504 \&$ n.59, 513 \& n.63 (majority of cases hold that child support must continue despite violation of custody decree as to visitation). But see Hudson v. Hudson, 412 N.Y.S.2d 242 (Sup. Ct. 1978) (child-support arrearages of father cancelled by court because of mother's interference with his visitation rights); cf. N.Y. DoM. REI.. LAw \$ 241 (McKinney Supp. 1978) (court may suspend alimony payments or cancel arrears if custodial parent wrongfully interferes with or withholds visitation); H. CLARK, supra note 6 , at $538 \& \mathrm{n} .11$ (many cases refuse recovery for alimony if custodial parent violates provisions of separation agreement).

54. See, e.g., Johnson v. Johnson, 52 Ohio App. 2d 180, 368 N.E.2d 1273 (1977). 
consuming and expensive to enforce promises in court. There can be substantial advantages, therefore, from the perspective of one or both bargainers, in having piecemeal bargains that spread support payments over time and, as a practical matter, link the custody issue (especially visitation) with the financial issues. ${ }^{55}$ If a father who values visitation fails to make support payments, then, quite apart from the mother's ability to enforce his promise in court (which may often be too slow and expensive to be effective), the mother may believe that she can retaliate by informally cutting off the father's visitation or making it more difficult. Even though this tactic has no legal validity, it is nevertheless likely to be faster, cheaper, and more effective than court enforcement. Similarly, a father may believe that his ability to cut off support will ensure that the mother will keep her word concerning visitation. ${ }^{56}$

55. Thomas Schelling has pointed out the advantages of the "tactic of decomposition" to "cultivate the necessary mutual expectations" for agreements to be reached. Schelling, An Essay on Bargaining, in Bargaining 336 (O. Young ed. 1975). He gives the following example: Two individuals do not particularly trust one another. Each wishes to give $\$ 1,000,000$ to the Red Cross, but only if the other also gives $\$ 1,000,000$. In a world where their mutual promises cannot be enforced in court, "each may be tempted to cheat if the other contributes first, and each one's anticipation of the other's cheating will inhibit agreement." Id. Schelling points out, however, that

if the contribution is divided into consecutive small contributions, . . . each can keep the other on short tether to the finish, [and] no one ever need risk more than one small contribution at a time. Finally, this change in the incentive structure itself takes most of the risk out of the initial contribution; the value of established trust is made obviously visible to both.

Id. at 336-37.

The tactic of decomposition, or piecemeal bargains, seems relevant in the divorce context. It suggests why visitation and support will often be intertwined. Suppose divorcing parents have a nine-year-old child. The mother might say to the father, "I will agree to be the child's primary custodian. Your share of child support during the remainder of his minority is $\$ 25,000$. Pay me this amount now, I will raise the child, and I promise not to interfere with your right to visit your child on a reasonable basis." Let us assume that the father thinks that the $\$ 25,000$ is a reasonable amount for child support, and wants the mother to be primary custodian. Nevertheless, if the father thinks that there are risks that the mother might try to inhibit visitation, and if enforcement of visitation rights is difficult or expensive, he may much prefer dividing support payments to the mother into monthly installments, the discounted value of which equals $\$ 25,000$. By spreading the support payments over time, the father would retain the practical power of retaliation. Although interference with visitation may not be a defense to the failure to make support payments, see note 53 supra, the father could effectively shift the enforcement burdens of collecting support to the wife. If payments are spread over time, the wife, of course, assumes the risk that the husband may fail to make a promised payment. See p. 962 supra. Nevertheless, apart from suing the husband for breach, she may have an effective practical remedy as well: she can make visitation more difficult for the husband. If visitation is important to the father, this may act as an important deterrent.

56. This is not as normatively distasteful, in terms of its effect on the child, as it may seem at first glance. If withholding support payments is an effective way of ensuring that the custodial spouse will not interfere with court-ordered visitation, it is certainly not as potentially damaging to the child as the legally sanctioned alternatives: calling out the sheriff to force surrender of the child, or moving for a contempt order that would put the custodial parent in jail until a promise to comply with visitation is exacted. 
The links between support and visitation are nurtured not only by the parties' power to take self-help measures, but also by important cultural values. Many believe that support obligations and visitation rights are inextricably tied together in terms of what it means to be a parent. A father who fails to support his children, at least when he has the financial capacity to do so, may in popular perception no longer be entitled to maintain a relationship with his minor children if the custodial mother objects. Similarly, a mother who purposely prevents a father from maintaining his relationship with his children after a divorce may be viewed as no longer entitled to his support.

\section{B. Toward a Theory of Divorce Bargaining}

Ideally, a bargaining theory would allow us to predict how alternative legal rules would affect negotiations between particular spouses and the deal, if any, they would strike. Such a theory might be combined with knowledge of how the characteristics that determine bargaining behavior are distributed among divorcing couples. Alternative rules and procedures could then be compared by evaluating the patterns of bargains that would result under each. Unfortunately, no existing theory of bargaining allows confident prediction of how different legal rules and procedures would influence outcomes; nor is there much information about current patterns and outcomes of the bargaining process.

What follows is not a complete theory. Instead, we identify five factors that seem to be important influences or determinants of the outcomes of bargaining, and then offer some observations on the bargaining process. The factors are (1) the preferences of the divorcing parents; (2) the bargaining endowments created by legal rules that indicate the particular allocation a court will impose if the parties fail to reach agreement; (3) the degree of uncertainty concerning the legal outcome if the parties go to court, which is linked to the parties' attitudes towards risk; (4) transaction costs and the parties' respective abilities to bear them; and (5) strategic behavior.

\section{Parental Preferences}

Parental preferences vary with regard to money and child-rearing responsibilities. Ordinarily, economists assume that a person's tastes for most goods and services are insatiable: no matter how much a person has, he will see himself as better off with more. This is cer- 
tainly a reasonably apt description of most people's taste for money; other things being equal, nearly everyone would prefer having more money to having less. ${ }^{57}$ This is not to say, of course, that people view the relative importance of money in the same way.

Preferences with regard to custody, however, probably vary a great deal more from person to person. Many individuals like spending time with their children and are willing to sacrifice a great deal in order to have child-rearing responsibilities. Sadly, some parents might pay a great deal to avoid child-rearing tasks altogether. There are also a wide variety of prerogatives and duties associated with child rearing, and parental preferences may vary among them. A parent may value very highly some tasks, like reading the child a bedtime story, and place negative value on others, like shopping for school clothes. Preferences may vary depending on how much custody a parent has; a parent will not necessarily prefer more. Some parents with limited child-rearing responsibilities may be willing to sacrifice money for additional custody up to a certain point; but once they have "enough" custody, they may be willing to give up money to avoid additional responsibility. For other parents, no amount of money can adequately compensate for a reduction in custody below a certain minimum level. Above that point, however, trade-offs between money and custody would be consistent with their tastes.

Informed bargaining requires a parent to assess accurately his or her own preferences concerning custodial alternatives. Yet the assessments are difficult and complicated. The information each parent has relates to the actual division of child-rearing tasks in an ongoing family. Dissolution or divorce inevitably alters this division, and the parent may discover new advantages or disadvantages to child-rearing responsibilities. Moreover, the parents' own needs may alter drastically after divorce. ${ }^{58} \mathrm{~A}$ parent interested in dating may find the child an intrusion in a way that the child never was during marriage. Additionally, a parent's interest in children may vary according to their age. Because children and parents both change, and changes may be unpredictable, projecting parental preferences for custody ten years into the future is a formidable task. Nevertheless, most parents have some self-awareness, however imperfect, and no third party (such as

57. See E. Mansfield, Mrcroeconomics $21-49$ (2d ed. 1975).

58. See Hetherington, Cox \& Cox, The Aftermath of Divorce, in Mother/ChiLd Father/Child ReLationships 162-73 (J. Stevens \& M. Mathews eds. 1978); Wallerstein \& Kelly, Divorce Counseling: A Community Service for Families in the Midst of Divorce, 47 AM. J. ORthopsychiatry 4, 6 (1977). 
a judge) is likely to have better information about a parent's tastes, present or future. ${ }^{59}$

Parental preferences, of course, will not generally be determined solely by self-interested judgments; a bargaining theory must take note of possible altruism or spite. One hopes that parental preferences reflect a desire for their children's happiness and well-being, quite apart from any parental advantage. ${ }^{60}$

For example, a father may commit himself to child-support payments beyond what he predicts a court would require, simply because he does not want his children to suffer economic detriment from a divorce. A mother may agree to substantial visitation for the father because she thinks this is good for the children, even though she personally despises the father and wants nothing more to do with him. Similarly, either or both spouses may have preferences that attach great weight to the happiness and desires of their former spouse.

At the other extreme, one can easily imagine preferences that reflect spite and envy. A spouse may simply have a strong wish to punish the other spouse, regardless of the detriment to himself or to the children. An angry parent may engage in a protracted and largely hopeless custody fight, exhausting his financial reserves and bringing emotional torment to the children, simply to punish his spouse.

\section{How Legal Rules Create Bargaining Endowments}

Divorcing parents do not bargain over the division of family wealth and custodial prerogatives in a vacuum; they bargain in the shadow of the law. The legal rules governing alimony, child support, marital property, and custody give each parent certain claims based on what each would get if the case went to trial. In other words, the outcome that the law will impose if no agreement is reached gives each parent certain bargaining chips-an endowment of sorts.

A simplified example may be illustrative. Assume that in disputed custody cases the law flatly provided that all mothers had the right to custody of minor children and that all fathers only had the right to visitation two weekends a month. Absent some contrary agreement

59. See note 29 supra. A major role for lawyers in the divorce process is to help clients clarify their own preferences. See p. 985 infra (lawyer's role as counselor); cf. ABA Code of Professional Responsibility EC 7.8 (1976) (duty of lawyer to ensure that client is fully informed of all relevant considerations).

60. Obviously, one can get into substantial linguistic tangles here. See G. Harman, The Nature of MORAlity 137-39 (1977) (problem of differentiating self-interest from desire to promote welfare of others). 
acceptable to both parents, a court would order this arrangement. Assume further that the legal rules relating to marital property, alimony, and child support gave the mother some determinate share of the family's economic resources. In negotiations under this regime, neither spouse would ever consent to a division that left him or her worse off than if he or she insisted on going to court. The range of negotiated outcomes would be limited to those that leave both parents as well off as they would be in the absence of a bargain. ${ }^{61}$

If private ordering were allowed, we would not necessarily expect parents to split custody and money the way a judge would if they failed to agree. The father might well negotiate for more child-time and the mother for less. This result might occur either because the father made the mother better off by giving her additional money to compensate her for accepting less child-time, or because the mother found custody burdensome and considered herself better off with less custody. Indeed, she might agree to accept less money, or even to pay the father, if he agreed to relieve her of some child-rearing responsibilities. In all events, because the parents' tastes with regard to the trade-offs between money and child-time may differ, it will often be possible for the parties to negotiate some outcome that makes both better off than they would be if they simply accepted the result a court would impose.

\section{Private Ordering Against a Backdrop of Uncertainty}

Legal rules are generally not as simple or straightforward as is suggested by the last example. Often, the outcome in court is far from certain, with any number of outcomes possible. Indeed, existing legal standards governing custody, alimony, child support, and marital property are all striking for their lack of precision and thus provide a bargaining backdrop clouded by uncertainty. The almost universal judicial standard for resolving custody disputes is the "best interests of the child." ${ }^{2}$ Except in situations when one parent poses a substantial threat to the child's well-being, predicting who will get custody under this standard is difficult indeed, especially given the increasing pressure to reject any presumption in favor of maternal

61. This analysis rests on the assumption that a spouse will act in his own self-interest. The conclusion allows for altruism or spite, provided that a spouse's preferences meet certain requirements of consistency. In particular, each spouse must be able to rank every possible combination of money/custody divisions in a way that is "transitive." In other words, if a spouse prefers custody/money division $A$ to division $B$, and prefers division $B$ to division $C$, then the spouse must also prefer division $A$ to division $C$.

62. See Mnookin, supra note 24, at 236-37 \& nn.45-47 (citing statutes and cases). 
custody ${ }^{63}$ Similarly, standards governing alimony and child support are also extraordinarily vague and allow courts broad discretion in disputed cases. ${ }^{64}$

Analyzing the effects of uncertainty on bargaining is an extremely complicated task. It is apparent, however, that the effects in any particular case will depend in part on the attitudes of the two spouses toward risk-what economists call "risk preferences." 65 This can be illustrated by considering a mechanism suggested in Beyond the Best Interests of the Child ${ }^{66}$ for resolving custody disputes between equally acceptable spouses: they would draw straws, with the winner getting full custodial rights and the loser none. ${ }^{67}$

Because drawing straws, like flipping a coin, ${ }^{68}$ gives each parent a fifty percent chance of receiving full custody, economic theory suggests that for each parent the "expected" outcome is half-custody. ${ }^{69}$ We cannot, however, simply assume that each parent will bargain as if receiving half of the child's time were certain. Attitudes toward

63. See id. at 235-36.

64. See J. AREEN, supra note 43, at 653 ("Statutes which authorize courts to award child support tend to be written in so general a fashion as to leave judges almost total discretion in the matter."); H. CLARK, supra note 6, at 3 (precedents on alimony of "slight value"; "relevant factors [in determining alimony] are so numerous and their influence so incapable of precise evaluation" that trial judge has great discretion); cf. White \& Stone, A Study of Alimony and Child Support Rulings with Some Recommendations, 10 FAM. L.Q. 75 (1976) (statistical study of 1,300 cases in Florida county determined that there was little consistency among trial judges as to which variables in determining alimony and child support were significant, though high degree of individual predictability was apparent).

It is more difficult to generalize about marital-property standards than about alimony or child support. The governing standards with regard to marital property appear in many jurisdictions to be more precise than those relating to custody, alimony, or child support. Predicting how a court will treat marital property is rather straightforward in community-property states that require equal division and in common law states that normally apply the doctrine of equitable apportionment only in exceptional circumstances. See J. AREen, supra note 43, at 636-37. But in those community-property or common law jurisdictions in which the court has broad discretion in dividing marital property, the outcome if the parties resort to court will obviously be more uncertain. See generally I. Baxter, Marital Property (1973); H. Clark, supra note 6, at 449-52; W. RePpy \& W. DeFuniak, Community Property in the United States (1975). At any rate, the following generalization made by a commentator 40 years ago still seems apt: "Judicial discretion is probably nowhere... given freer rein, than in the field of domestic relations." Cooey, The Exercise of Judicial Discretion in the Award of Alimony, 6 LAw \& Contemp. Prob. 213, 213 (1939).

65. See R. Luce \& H. Raiffa, Games and Decisions 12-38 (1957) (introduction to problems of utility theory and decisionmaking under uncertainty); H. RAIFFA, Decision ANalysis 7-38 (1968) (same).

66. J. Goldstein, A. Freud \& A. Solnit, Beyond the Best Interests of the Child (1973).

67. Id. at 153 .

68. See generally Mnookin, supra note 24 , at 289-91.

69. See generally P. Hoel, S. Port \& C. Stone, Introduction to Probability Theory 48-108 (1971) (discussing mathematical expectations). 
risk may be defined by asking a parent to compare two alternatives: (1) a certainty of having one-half of the child's time; or (2) a gamble in which the "expected" or average outcome is one-half of the child's time. By definition, a parent who treats these alternatives as equally desirable is risk-neutral. A parent who would accept a certain outcome of less than half-custody in order to avoid the gamble-the chance of losing the coin flip and receiving no custody-is risk-averse. Other parents may be risk preferers: they would rather take the gamble and have a fifty percent chance of winning full custody than accept the certain outcome of split custody.

The reality of custody litigation is more complicated, and the knowledge of the parties much less complete, than in our hypothetical. The parties in the example know the standard for decision and the odds of winning custody in court. But in real situations, the exact odds of various possible outcomes are not known by the parties; often they do not even know what information or criteria the judge will use in deciding. ${ }^{70}$

\section{Transaction Costs}

Costs are involved in resolving the distributional consequences of separation or divorce, and in securing the divorce itself. The transaction $\operatorname{costs}^{71}$ that the parties must bear may take many forms, some financial and some emotional. The most obvious and tangible involve the expenditure of money. Professional fees-particularly for lawyersmust be paid by one or both parties. ${ }^{72}$ In addition, there are filing

\section{See note 64 supra.}

71. See generally R. Posner, Economic Analysis of Law 434-41, 445.47 (2d ed. 1977) (analyzing effect of costs of legal process on decision of parties whether to settle or go to trial).

72. The general rule in civil litigation is that, absent express statutory authority to award fees and costs, each party bears his or her own attorneys' fees. In many jurisdictions, however, attorncys' fees in divorce actions are an exception to this general rule. In Connecticut, for example, although there is no statutory provision with respect to attorneys' fees, it appears that courts often require husbands to pay the fees of their wives. See Buchman, Post Divorce Decree Awards of Counsel Fees, 44 ConN. B.J. 359, 359-61 (1970). In Texas, courts have included attorneys' fees within the "doctrine of necessaries," under which each spouse has a duty to support the other. This doctrine, codified in Tex. FAM. Code ANN. tit. 1, $\$ 4.02$ (Vernon 1975), is seen as giving authority for the discretionary award of attorneys' fees. See Comment, Award of Attorney's Fees in Divorce Litigation in Texas, 13 Hous. L. REv. 1016, 1016-17 (1976). Many other states have express statutory provisions allowing for an award of attorneys' fees to either party within the discretion of the court. See, e.g., CaL. Civ. Code $\S 4370$ (West Supp. 1979).

If a divorcing spouse cannot afford an attorney, and the other spouse lacks the means to pay for the attorney, it may be possible to secure legal assistance through legal aid. However, it has also been held that there is no constitutional right of indigents to stateprovided counsel for divorce. See In re Smiley, 36 N.Y.2d 433, 437-38, 330 N.E.2d 53, 55-58, 369 N.Y.S.2d 87, 90 (1975). 
fees and court costs. ${ }^{73}$ More difficult to measure, but also important, are the emotional and psychological costs involved in the dispute-settlement process. Lawsuits generally are emotionally burdensome; ${ }^{74}$ the psychological costs imposed by bargaining (and still more by litigation) are particularly acute in divorce. ${ }^{\tau \bar{\jmath}}$

The magnitude of these transaction costs, both actual and expected, can influence negotiations and the outcome of bargaining. In the dissolution process, one spouse, and that spouse's attorney, can substantially affect the magnitude of the transaction costs that must be borne by the other spouse. As is generally the case, the party better able to bear the transaction costs, whether financial or emotional, will have an advantage in divorce bargaining.

In divorce, transaction costs will generally tend to be (l) higher if there are minor children involved, because of the additional and intensely emotional allocational issues to be determined; (2) an increasing function of the amount of property and income the spouses have, since it is rational to spend more on negotiation when the possible rewards are higher; ${ }^{\text {ic }}$ and (3) higher when there is a broad range of possible outcomes in court.

\section{Strategic Behavior}

The actual bargain that is struck through negotiations-indeed, whether a bargain is struck at all-depends on the negotiation process. During this process, each party transmits information about his or her own preferences to the other. This information may be accurate or intentionally inaccurate; each party may promise, threaten, or bluff. ${ }^{77}$ Parties may intentionally exaggerate their chances of winning

73. Generally, the award of costs to either party is within the discretion of the court. See note 72 supra (citing sources). The Supreme Court has held that due process prohibits the state from denying, solely on the basis of inability to pay, access to courts for individuals seeking dissolution of marriage. Boddie v. Connecticut, 401 U.S. 371, 380.82 (1971).

74. See Address by Learned Hand, Association of the Bar of the City of New York (Nov. 17, 1921), excerpted in D. Louisell \& G. Hazard, Pleading and Procedure 1295 (3d ed. 1973) ("[A]s a litigant I should dread a lawsuit beyond almost anything else short of sickness and death.")

75. See, e.g., R. DeWolf, The Bonds of Acrimony 39-55 (1970).

76. Cf. R. Posner, supra note 71, at 436 ("other things being equal, the higher the stakes in a case the more likely it is to be litigated"); Cooter \& Kornhauser, Can Litigation Improve the Law Without the Help of Judges? (forthcoming). Cooter and Kornhauser suggest that the litigation rate may not be higher in disputes involving larger sums. Transaction costs may be higher even if the litigation rates are not because transaction costs include costs of settlement and attempted settlement. $I d$.

77. A father, for example, may pretend that he wants custody and is willing to litigate the issue simply to intimidate a risk-averse mother into settling for less money. See Law- 
in court in the hope of persuading the other side to accept less. Or they may threaten to impose substantial transaction costs-economic or psychological-on the other side. In short, there are a variety of ways in which the parties may engage in strategic behavior during the bargaining process. ${ }^{78}$

Opportunities for strategic behavior exist because the parties often will not know with certainty (I) the other side's true preferences with regard to the allocational outcomes; (2) the other spouse's preferences or attitudes towards risk; and (3) what the outcome in court will be, or even what the actual odds in court are. Although parents may know a great deal about each other's preferences for money and children, complete knowledge of the other spouse's attitudes is unlikely.

How do parties and their representatives actually behave during the process? Two alternative models are suggested by the literature: (I) a Strategic Model, which would characterize the process as "a relatively norm-free process centered on the transmutation of underlying bargaining strength into agreement by the exercise of power, horse-trading, threat, and bluff"; ${ }^{79}$ and (2) a Norm-Centered Model, which would characterize the process by elements normally associated with adjudication-the parties and their representatives would invoke rules, cite precedents, and engage in reasoned elaboration. ${ }^{80}$ Anecdotal observation suggests that each model captures part of the flavor of the process. The parties and their representatives do make appeals to legal and social norms in negotiation, but they frequently threaten and bluff as well. ${ }^{81}$

\section{The Task Facing the Spouses and the Process of Negotiation}

The task facing divorcing spouses can be summarized, based on the preceding analysis, as one of attempting through bargaining to divide money and child-rearing responsibilities to reflect personal preferences. Even though the interests of the two parents may substantially conflict, opportunities for making both parents better off

yering for the Child, supra note 27, at $1131 \mathrm{n} .21$ (citing interview with Assistant Clerk of New Haven Superior Court). The prevailing best interests standard exacerbates the disadvantages of a risk-averse parent because of its great uncertainty. See p. 979 infra.

78. The concept of strategic behavior is not without ambiguity. We use it to mean behavior in which the parties misrepresent their own intentions, desires, or chances of winning in order to obtain a strategic advantage in negotiation.

79. Eisenberg, supra note 1 , at 638 .

80. Id. at 638-39.

81. Cf. id. at $680-81$ (interplay of evocation of norms and use of bargaining power). 
through a negotiated agreement will exist to the extent that parental preferences differ. ${ }^{82}$

This analysis suggests why most divorcing couples never require adjudication for dispute settlement. The parties gain substantial advantages when they can reach an agreement concerning the distributional consequences of divorce. They can minimize the transaction costs involved in adjudication. They can avoid its risks and uncertainties, and negotiate an agreement that may better reflect their individual preferences.

Furthermore, divorcing spouses usually have no incentive to take cases to court for their precedential value. Unlike insurance companies, public-interest organizations, and other "repeat players," a divorcing spouse will generally have no expectation that an adjudicated case will create precedent, or that any precedent created will be of personal benefit in future litigation. ${ }^{83}$

Given the advantages of negotiated settlements, why do divorcing spouses ever require courtroom adjudication of their disputes? There are a variety of reasons why some divorce cases will be litigated:

1. Spite. One or both parties may be motivated in substantial measure by a desire to punish the other spouse, rather than simply to increase their own net worth.

2. Distaste for Negotiation. Even though it costs more, one or both parties may prefer the adjudicative process (with third-party decision) to any process that requires a voluntary agreement with the other spouse. Face-to-face contact may be extremely distasteful, and

82. The bargaining situation may be diagrammatically illustrated by using an "Edgeworth box," in which the two axes represent money and child-time. The trade offs for each spouse may be represented by indifference curves. The points of tangency of these curves, where the marginal rates of substitution between money and custody are identical for the two spouses, create a "contract curve" of Pareto-optimal outcomes. On Edgeworth boxes, see J. HeNDERson \& R. QuANDT, supra note 39, at 162-64.

83. Analysis of the incentives for litigation and for the creation of precedent is beginning to emerge. See, e.g., Landes \& Posner, Adjudication as a Private Good, $8 \mathrm{~J}$. LEGAL Stud. 235 (1979); Priest, The Common Law Process and the Selection of Efficient Rules, 6 J. Legal Stud. 65 (1977); Rubin, Why Is the Common Law Efficient? 6 J. Legal Stud. 51 (1977); Cooter \& Kornhauser, supra note 76. On the differences in incentives for litigation among various sorts of litigants, see Galanter, supra note 3. Galanter characterizes divorce and custody disputes as involving "one-shotters," $i d$. at 97, on both sides, rather than "repeat players," id. at 107.

It is interesting to speculate about whether the divorce bar ever has an interest in promoting certain sorts of litigation for their precedential value. In personal injury cases, for example, in which lawyers typically represent either plaintiffs or defendants exclusively, plaintiffs' attorneys may have an interest in precedent because they will continue to represent victims of accidents, never insurance companies. There is some specialization in the divorce bar, including lawyers who only represent husbands, or only represent wives. In such circumstances, the attorney may have an interest in precedent quite apart from the interests of any particular client. 
the parties may not be able to negotiate-even with lawyers acting as intermediaries-because of distrust or distaste.

3. Calling the Bluff-The Breakdown of Negotiations. If the parties get heavily engaged in strategic behavior and get carried away with making threats, a courtroom battle may result, despite both parties' preference for a settlement. Negotiations may resemble a game of "chicken" in which two teenagers set their cars on a collision course to see who turns first. Some crack-ups may result.

4. Uncertainty and Risk Preferences. The exact odds for any given outcome in court are unknown, and it has been suggested that litigants typically overestimate their chances of winning. ${ }^{s t}$ To the extent that one or both of the parties typically overestimate their chances of winning, more cases will be litigated than in a world in which the outcome is uncertain but the odds are known. In any event, when the outcome is uncertain, settlement prospects depend on the risk preferences of the two spouses. ${ }^{85}$

5. No Middle Ground. If the object of dispute cannot be divided into small enough increments-whether because of the 1 law, ${ }^{86}$ the practical circumstances, ${ }^{87}$ or the nature of the subject at issue ${ }^{88}$ there may be no middle ground on which to strike a feasible compromise. Optimal bargaining occurs when, in economic terminology, nothing is indivisible.

These points can be illustrated through a simple example. Assume a divorcing couple has no children and the only issue is how they will divide 100 shares of stock worth $\$ 10,000$. Let us further assume that it would cost each spouse $\$ 1,000$ to have a court decide this issue, and that each spouse must pay his own litigation costs.

If the outcome in court were entirely certain, would the parties ever litigate? Suppose it were clear that a court would inevitably

84. See Aubert, Courts and Conflict Resolution, II J. Conflict Resolution 40, 44 (1967).

85. See p. 970 supra.

86. Child custody would have limited divisibility in jurisdictions in which joint custody is forbidden or actively discouraged by courts, see, e.g., Rickard v. Rickard, 7 Wash. App. 907, 503 P.2d 763 (1972), petition for review denied, 81 Wash. 2d 1012, 503 P.2d 763 (1973) (joint custody to be avoided if possible and ordered only in exceptional circumstances); Martin v. Martin, 132 S.W.2d 426 (Tex. Civ. App. 1939) (child cannot grow up normally with split custody), or if the proposal of Beyond the Best Interests of the Child were adopted, see pp. 980-83 infra.

87. If the parents live a great distance from each other, it may not be possible to divide child-time between them in a manner reflecting their preferences.

88. This would be the case, for example, if there were one piece of marital property so valuable, for sentimental or other reasons, that neither party could be compensated for giving up his share by getting all the couple's other assets, and if neither party would consent to its being auctioned off. 
award one-half of the stock to each spouse because it would be characterized as community property. If the issue were litigated, each spouse would end up with only $\$ 4,000$. A spouse would therefore never accept a settlement offer of less than $\$ 4,000$. One might expect that the parties would normally simply settle for $\$ 5,000$, and save the costs of litigation. Taking the issue to court would substitute an expensive mode of dispute resolution-adjudication-for a cheaper mode-negotiation.

Even when the outcome in court is certain, litigation is still possible. A spouse might engage in strategic behavior and threaten to litigate in order to get more than half. Suppose the husband threatened to litigate unless the wife agreed to accept a settlement of $\$ 4,500$. The wife might accept $\$ 4,500$ but only if she believed the threat. She would know with proper legal advice that her husband would only end up with $\$ 4,000$ if he litigated. Therefore the threat ordinarily would not be credible. She might call his bluff and tell him to sue. If the wife were convinced, however, that her husband was motivated by spite and in fact preferred to litigate rather than accept less than $\$ 5,500$, she might accept $\$ 4,500$. If the outcome in court is certain, then, absent spite, strategic behavior, or a distaste for negotiations, adjudication should not generally occur; litigation would impose an expensive mode of dispute settlement when a less expensive alternative could achieve the same result.

What about cases in which the result in court is uncertain? Assume, for example, that there is a fifty percent chance that the husband will get all $\$ 10,000$, and a fifty percent chance that the wife will get all $\$ 10,000{ }^{89}$ Settlement in these circumstances obviously depends on the risk preferences of the two spouses. If both are riskneutral, then both will negotiate the same way as they would if they knew for certain that a court would award each of them $\$ 5,000-$ the "expected" value of the litigation in this case.

To the extent that the parties are both risk-averse-each is prepared to accept less than $\$ 5,000$ to avoid the risks of litigation-the parties have a broader range of possible settlements that both would prefer to the risks of litigation. This may facilitate agreement.

Conversely, if both parties are risk preferers-each prefers the gamble to an offer of the expected value of $\$ 5,000$-all cases are likely to

89. In real cases, the parties do not know the probability distribution of the various outcomes a court might impose. This injects a further complication in the process and creates the possibility that one or both parties may overestimate their own chances of winning. This may result in more cases being litigated than in a world where the outcome is uncertain but the odds are known. 
be litigated. When one party is a risk preferer and the other is riskaverse, it is difficult to predict the effect on the rate of litigation. In any negotiated outcome, a risk preferer will have an advantage over the party who is risk-averse.

\section{The Bargaining Framework Applied}

\section{A. Custody Standards: The Rule/Discretion Debate Revisited}

There has been considerable debate about the advantages and disadvantages of legal standards that confer broad discretionary power on decisionmakers. ${ }^{90}$ But analysis has generally focused, both in the family law context and elsewhere, on the effects of discretion on the decisionmaking behavior of officials. We would like to suggest a different perspective, focusing on the implications of discretionary standards when they serve as the backdrop for out-of-court negotiations by the parties themselves.

The effect on the process of divorce bargaining of having more or less precise standards can be fruitfully explored by comparing and contrasting the effects of three different custody standards, each of which has proponents in current policy discussion:

1. A maternal-preference rule creates a strong presumption in favor of giving custody to a mother, with the father having limited visitation rights. ${ }^{91}$ Until recently, this was the dominant standard. ${ }^{92}$

2. The best interests of the child standard calls for a highly individualized determination, confers broad discretion on the judge, and gives no automatic preference to either parent simply on the basis of the parent's or the child's sex..$^{93}$ This standard seems to be the dominant one today. ${ }^{94} \mathrm{We}$ will assume that ordinarily the parent who is awarded custody will have care and control of the child for all but two weekends a month, during which time the other spouse will have visitation rights.

3. A joint-custody rule provides that in disputed cases each parent will have care and control of a child for half the time. Although it

90. See, e.g., K. Davis, Discretionary Justice (1969); P. Nonet, AdMinistrative Justice (1969); R. POSNER, supra note 71, at 424-25; Note, The Void-for-Vagueness Doctrine in the Supreme Court, 109 U. PA. L. REv. 67 (1960).

91. See, e.g., R. LEVY, supra note 41 , at $224-25$ (recommending presumption that wife be entitled to custody); Watson, supra note 37 , at 82 (maternal preference for children under 10, plus same-sex presumption for older children). See generally Mnookin, supra note 24 , at $135-36,283-84$.

92. See Mnookin, supra note 24, at 235-36.

93. See id. at 231-32, 235, 255-56.

94. Id. at 236. 
has been seriously proposed, ${ }^{9 \overline{5}}$ no jurisdiction has adopted this rule.

Each of these three custody standards creates its own set of bargaining endowments. Because different rules give various amounts of bargaining chips to the parties, changing the standard would affect each party's relative bargaining power and would therefore influence the range and frequency of possible negotiated outcomes.

For example, if the legal standard were changed from a maternalpreference rule to a standard that gave no preference based on parental sex, then a father's chances of winning custody in a contested case would be improved. This in turn would affect the outcomes reached through negotiation, since it would generally increase the bargaining power of fathers as a class and decrease the bargaining power of mothers. Because of differences in parental preferences, however, not all fathers would end up with more child-time: some might simply pay less in alimony or child support. Thus, our analysis suggests that recent changes in custody law giving fathers more equal claims to custody, and in alimony law limiting the extent and availability of permanent alimony, ${ }^{96}$ have strengthened the relative bargaining power of husbands.

Both the best interests standard and the joint-custody rule are "neutral" as between the sexes; nevertheless, they have very different implications for bargaining. Under the best interests principle the outcome in court will often be uncertain: each spouse may be able to make a plausible claim for custody, and it may be impossible to predict how a court would decide a disputed case. Under the jointcustody standard, on the other hand, the parties both know what will happen in court: each will be responsible for the child half the time. Thus, comparison of these two standards allows us to explore further the effects of uncertainty on the bargaining process.

Uncertainty has several important effects on the relative bargaining power of the parties. As suggested earlier, if there is substantial

95. Traditionally, courts have been unwilling to approve joint, split, or divided custody arrangements for small children. See, e.g., Utley v. Utley, 364 A.2d 1167 (D.C. 1976); McLemore v. McLemore, 346 S.W.2d 722 (Ky. 1961); Martin v. Martin, 132 S.W.2d 426 (Tex. Civ. App. 1939). More recently, however, some jurisdictions have been willing to approve joint-custody arrangements when both parents desire such. See, e.g., Childers v, O'Neal, 251 Ark. 1097, 476 S.W.2d 799 (1972); Perotti v. Perotti, 78 Misc. 2d 131, 355 N.Y.S.2d 68 (1974) (relitigated with custody awarded to father in unreported decision dated July 18, 1975; see Dodd v. Dodd, 93 Misc. 2d 641, 647, 403 N.Y.S.2d 401, 405 (1978)). Some commentators today recommend joint custody as the superior alternative. See note 51 supra.

96. Commentators have suggested, for example, a trend "toward rehabilitative alimony and away from permanent alimony." White \& Stone, supra note 64, at 80 . For a chart summarizing changes in alimony laws, see Freed \& Foster, supra note 13, at 309-10. 
variance among the possible court-imposed outcomes, the relatively more risk-averse party is comparatively disadvantaged..$^{97}$ The important policy implications of this fact are illustrated by the following example.

Assume that both the parents would like to have custody. The father is risk-neutral; he would be indifferent if given a choice between (1) having custody of his child half the time; or (2) being exposed to ádjudication under the best interests standard and having a fifty percent chance of winning full custodial rights and a fifty percent chance of only having visitation rights. The mother, on the other hand, we will assume is risk-averse; she would much prefer the certainty of half the child's time to the risk of adjudication with a fifty percent chance that she might end up only with visitation.

We would predict that under the best interests standard the mother, because she is risk-averse, will accept less in order to avoid the gamble inherent in adjudication. Both custody standards are "sex neutral," yet the best interests standard disadvantages a risk-averse parent and the joint-custody rule does not. The fact that uncertainty about the outcome in court concerning custody disadvantages the relatively more risk-averse parent is a peculiarly ironic and tragic result. Most of us would assume that a good parent would be unwilling to take a gamble in which one outcome would substantially diminish his or her relationship with the child. And yet the consequence of a vague, discretionary rule is to disadvantage such a parent if he or she is negotiating with a spouse who is more of a gambler. ${ }^{98}$

Vague legal standards have other effects on the parties' relative bargaining power and on negotiations. Uncertainty about the outcome in court probably increases transaction costs. Imprecise legal standards require an expert to estimate the probable outcome if the parties go to court. A lawyer may be necessary simply for a person to learn what his bargaining chips are. Moreover, because there may be no objective source of information about the actual probabilities of outcome in a particular case, the parties and their representatives may spend considerable time attempting to persuade the other side that it has overestimated its prospects for success.

It would also seem that vague legal standards give a relative advantage to the more able negotiator. As the dispersion among possible outcomes in court becomes wider, there will be a greater premium

97. See p. 977 supra.

98. Solomon's threat to cut the child in half was perhaps founded on a belief that the child's real mother would be more risk-averse than the false claimant. 
on bargaining skills, since there will be greater opportunities for strategic behavior and a wider range of possible negotiated outcomes that might leave a party better off than possible court-imposed outcomes.

This analysis does not suggest any easy answer to the question about the appropriate custody standard. It does show the importance of analyzing the effects of legal standards on the dispute-settlement process outside of court. Discretionary standards can substantially affect the relative bargaining strength of the two parties, primarily because their attitudes toward risk and capacities to bear transaction costs may differ substantially.

Uncertainty can be reduced by making the legal standards more precise. But, as demise of the maternal-preference rule suggests, certainty may be achievable only if we elevate the importance of a criterion that is no longer considered appropriate.

Evaluation of the joint-custody rule suggests another dilemma: a standard may have good characteristics as a background rule for private ordering but may nevertheless be unacceptable as a standard for adjudicating disputed cases. The advantages of the joint-custody rule from the perspective of bargaining are that it does not disadvantage the relatively risk-averse parent, reduces the scope for strategic behavior, and imposes lower transaction costs. Nevertheless, it would probably be disastrous to impose joint custody on the parties if they could not agree to it themselves, since joint custody normally requires a very high degree of parental cooperation. Without such cooperation, the substantial contact both parents would have with the child, and necessarily with each other, would create endless possibilities for antagonism between the parents, with predictably detrimental effects on the child's well-being. ${ }^{90}$ Ordering joint custody may be very much like carrying out Solomon's threat to cut the child in half.

B. The Visitation Proposal of Beyond the Best Interests of the Child: How Limiting the Power to Make Binding Promises Can Affect Dispute Settlement

The importance of analyzing the effects of reform proposals on private ordering is dramatically illustrated by consideration of the

99. See, e.g., Braiman v. Braiman, 44 N.Y.2d 584, 589-90, 378 N.E.2d 1019, 1021, 407 N.Y.S.2d 449, 451 (1978) ("[J]oint custody is encouraged primarily as a voluntary alternative for relatively stable, amicable parents behaving in mature civilized fashion .... As a court-ordered arrangement imposed upon already embattled and embittered parents, accusing one another of serious vices and wrongs, it can only enhance familial chaos.") (citations omitted). 
legal standard for visitation proposed in Goldstein, Freud, and Solnit's Beyond the Best Interests of the Child. ${ }^{\mathbf{1 0 0}}$ They recommend that

[o]nce it is determined [by agreement of the divorcing parents or by the court in the absence of agreement] who will be the custodial parent, it is that parent, not the court, who must decide under what conditions he or she wishes to raise the child. Thus, the noncustodial parent should have no legally enforceable right to visit the child, and the custodial parent should have the right to decide whether it is desirable for the child to have such visits. ${ }^{101}$

Much ink has been spilled over this controversial proposal. ${ }^{102}$ Many behavioral scientists have suggested the importance from the child's perspective of maintaining contact with the noncustodial parent. ${ }^{103}$ Lawyers have challenged the proposal on grounds of fairness. ${ }^{104}$ But the critics-like the authors themselves-have largely failed to consider the possible effects of the proposed standard on private ordering. ${ }^{105}$

From our perspective it is useful to ask what power the parents would have to make their own law with respect to custodial arrangements. This question points up a peculiar inconsistency. The book makes it clear that the parents would have the right and the power to determine by agreement "who will be the custodial parent."106 A court would determine the custodial parent only if there were a

100. J. Goldstein, A. Freud \& A. Solnit, supra note 66.

101. Id. at 38 (footnote omitted).

102. See, e.g., Katkin, Bullington \& Levine, Above and Beyond the Best Interests of the Child: An Inquiry into the Relationship Between Social Science and Social Action, 8 Law \& Soc'y Rev. 669, 680 (1974); Dembitz, Book Review, 83 Yale L.J. 1304, 1310 (1974); Strauss \& Strauss, Book Review, 74 ColuM. L. REv. 996, 1002-05 (1974).

103. See, e.g., Katkin, Bullington \& Levine, supra note 102, at $672-75$ (criticizing lack of data base for visitation proposal and excessive reliance on inapposite or discredited studies); Strauss \& Strauss, supra note 102, at 1002 ('given a child with existing relationships to both, we know of no [psychological] studies which show that the legal death of one parent, the complete subordination of the child to the other's possibly distorted vicw, is invariably the preferable step for its future development"); cf. Kelly \& Wallerstein, Part-Time Parent, Part-Time Child: Visiting After Divorce, 1977 J. Cunical Chrud Psych. 51 (extensive study emphasizing importance to child of visiting noncustodial parent).

104. See, e.g., Dembitz, supra note 102, at 1310 (characterizing proposal as "blind and untenable"); Strauss \& Strauss, supra note 102, at 1001 (noting that parent has claim independent of child).

105. The one clear exception is the review by Strauss \& Strauss, supra note 102, at 1002-04. Katkin, Bullington \& Levine, supra note 102, are concerned with the failure of Goldstein, Freud, and Solnit to consider how individuals might "circumvent" their proposals generally. And Katkin, Bullington, and Levine do suggest that the visitation proposals "might generate pressures to keep families intact" when a divorce might be more beneficial. Id. at 680 .

106. J. Goldstein, A Freud \& A. Solnit, supra note 66 , at 38 . 
dispute-i.e., "in the event each claims custody"; ${ }^{107}$ if the parents agreed, presumably a court would have no right to override their determination. What is strange, however, is the extreme limitation on the parents' legal powers: they can decide who will have full custodial rights, but they have no power to bind themselves legally to some alternative division of responsibilities concerning the child. For example, they would not be able to make an enforceable agreement giving the noncustodial parent visitation rights, nor could they make a binding agreement to have joint custody.

The authors do not explain why parents, rather than a state official, should be trusted to make the determination of who will have all legal power over the child, but should lack the power to make their own law concerning some less extreme alternative. ${ }^{108}$ The purpose of their proposed rule was to ensure that every child had a substantial and uninterruptible psychological relationship with at least one parent. ${ }^{109}$ The book is highly critical of the fact that under existing law custodial arrangements have no finality; they can be relitigated easily in the future. One advantage the authors would see in their rule, no doubt, would be that it would avoid courtroom disputes in the future by making it clear that the custodial parent had all the bargaining chips.

But the authors entirely fail to consider the possible effects of such a rule on the ability of parents to reach an initial agreement concerning custody. The parents are allowed to agree only on that outcome about which they are least likely to agree: total legal custody or none. Because parents would lack the power to make binding promises concerning any intermediate allocation, this rule would be likely to create more custody disputes at the time of divorce. It might also have unanticipated effects on support payments by the noncustodial parent.

Suppose, for example, that a father's initial preference is that custody essentially be given to the mother, but with substantial paternal visitation rights-two days every weekend and six weeks in the summer. If he were to choose, however, between having exclusive custody

107. Id. at 38 n.*.

108. A more forceful argument against the Goldstein, Freud, and Solnit proposal, suggested by Strauss \& Strauss, supra note 102 , is that it violates the authors' own value preference for minimum governmental intrusion on parental rights to raise their children, see J. GoldsteIn, A. FREUD \& A. Solnit, supra note 66, at 7-8. The effect of the visitation proposal would be to make one parent a legal "stranger to his child" (though not without obligations) without a finding of abuse or neglect. Strauss \& Strauss, supra note 102, at 1002.

109. See J. Goldstein, A. Freud \& A. SolNit, supra note 66, at 6, 37-38. 
himself or having no visitation rights whatsoever, he would prefer exclusive custody. Such preferences not only seem plausible, but perhaps even common. What would such a father do under the Goldstein, Freud, and Solnit scheme? An agreement that the mother would be "the custodial parent" would mean that the father's power to maintain a relationship with his children was entirely within her discretion, at least while the children were young. He would have no legal recourse if she ever refused to permit visitation.

Even assuming that the mother were willing to promise the father the visitation rights he wants, she would have no power whatsoever to bind herself legally to that agreement. The father might therefore realistically fear that she would exclude him at some time in the future-perhaps if she remarried-no matter what she promises now. To avoid that risk the father might reluctantly prefer a custody dispute in court, in which he at least has a chance of winning, to a settlement that gives him no legal right to see his children. ${ }^{110}$ Nowhere do the authors consider this possible consequence.

Nor do they consider the effects of their visitation proposal on support issues. Because the mother cannot bind herself concerning visitation, she may decide to accept less support money, provided the father does not contest custody. More generally, if visitation rights are granted at the whim of the custodial parent, the noncustodial parent may be less willing to commit himself concerning alimony and child support. ${ }^{111}$ By excluding the possibility of binding visitation agreements, the proposal may also inhibit arrangements that tie financial aspects to visitation in ways mutually desirable to the parents. If all of these consequences were considered, one might easily conclude that the risks that the visitation rule would create-more custody disputes at the time of divorce and more support disputes after divorce-outweigh the possible benefits of a reduction in visitation disputes after divorce.

This analysis of the Goldstein, Freud, and Solnit rule illustrates a point of more general importance: limitations on the parties' power to make legally enforceable promises may, in some cases, make dispute settlement more difficult. Professor Schelling has pointed out the importance for bargaining of being able to make a binding promise: "This need for promises is more than incidental; it has

110. This would mean not only an increase in litigated cases, but also an increase in custody claims that are disingenuous. In the hypothetical example, the father might ask the court for full custody only so that he could then cede much of the child-time back to his wife without having to worry about trusting his former spouse.

111. See pp. 963-66 supra (inextricable link between child support and visitation). 
an institutional importance of its own. It is not always easy to make a conxincing, self-binding, promise."112

One important function of the legal system is to provide an effective mechanism for redress if a promise is broken. Of course, the parties may still make promises even when they know in advance that there can be no court enforcement: they may simply trust each other, or they may view the risk of breach as so slight as to be unimportant. A promise may be effective because each party has pledged his or her reputation. Or, the parties may be able to persuade each other that, quite apart from what a court may do, the embarrassment of reneging will be sufficient to make a breach very costly. In many circumstances, because the parties each value their future relationship -and because there may be informal means of retaliation to punish a breach-court enforcement may not be decisive. Nevertheless, the inability to make an enforceable promise may inhibit dispute settlement.

This principle has application elsewhere in family law, as well as in other legal contexts. It points to a possible consequence of the legal rule permitting child support and custody to be reopened at any time. The rule prevents the parents from binding themselves permanently on custody and child support. The justification for the limitation is obvious: because people's lives change, an arrangement that benefits the child at one stage may not benefit the child at some later stage. There is reluctance to give parents the power to make permanently binding commitments that, in some cases, may later prove inimical to the child's interests. Nevertheless, this inability to make binding commitments may, as the criticism of the Goldstein, Freud, and Solnit proposal suggests, make dispute settlement through negotiation more difficult. Legal standards that permit modification only if there is a "substantial change in circumstances"113 can be seen as something of a compromise. They do not permit the parties to make permanent commitments, but instead make agreements very difficult, though not impossible, ${ }^{114}$ to reopen unilaterally.

112. Schelling, supra note 55 , at 335 .

113. J. AREEN, supra note 43, at 579; see Foster \& Freed, Child Custody (pt. 2), 39 N.Y.U. L. Rev. 615, 623 (1964); Annot., 61 A.L.R.3d 657 (1975).

114. How much of a compromise current modification standards represent will vary from jurisdiction to jurisdiction according to how high a barrier the legal standard poses. Compare Simons v. Simons, 172 Conn. 341, 346-50, 374 A.2d 1040, 1042-43 (1977) (requirement of material change of circumstances must be balanced against best interests standard and is one element in larger question of what is in child's best interests) with Perreault v. Cook, 114 N.H. 440, 443, 322 A.2d 610, 612 (1974) ("The relationship established by the custody award should not be disturbed unless the moving party demonstrates that the circumstances affecting the [child's] welfare ... have been so greatly altered that there 


\section{Lawyers in the Dispute Settlement Process}

Private ordering suggests new perspectives on the role of lawyers in divorce. It also provides a fresh view of the question of whether counsel should be appointed for the child.

\section{The Roles of Lawyers}

Lawyers perform a number of functions in the divorce process:

a. Source of information. Lawyers can provide the basic information about each spouse's bargaining endowment-the applicable legal norms and the probable outcome in court if the case is litigated. Indeed, as noted earlier, imprecision in the applicable legal standards increases one's need for legal advice. A rational client will want an accurate assessment of the possible costs of alternative modes of dispute settlement. Lawyers are also an important source of information about transaction costs, a major element of which will be legal fees. ${ }^{115}$

b. Counselor. The lawyer may help the parties determine what their real interests are. Divorcing spouses may not have carefully examined the financial questions or their own preferences for childrearing responsibilities.

c. Clerk. To secure a divorce, even when there is no dispute, it is typically necessary for certain legal procedures to be followed and for various forms to be completed. To the extent the forms and the procedures are intricate, divorcing couples may require legal assistance even though there is no dispute whatsoever. ${ }^{116}$

d. Negotiator. Lawyers can serve as negotiators with the other spouse or the other spouse's lawyer. Some parties may find negotiation extremely difficult, particularly given the anger and sense of guilt that often accompany divorce. Negotiators can be hired in the marketplace for legal services. ${ }^{117}$

is a strong possibility the child will be harmed if he continues to live under the present arrangement.") The standards will also vary in the time limits, if any, that are imposed. Compare Uniform MarRIaGe AND Divorce ACT $\$ 409$ (a) (enacted in five jurisdictions) (no motion to modify custody may be made earlier than two years after date of initial decree) with Conn. Gen. STA'r. \$ 46b-56(a) (1979) (court may modify custody order "at any time").

115. Other transaction costs of litigating are those imposed by the legal system-e.g., filing fees, court fees, etc. A lawyer will also be a source of information on the available strategies for inflicting emotional costs on the other party.

116. See Pro Se Divorce, supra note 26, at 123-29.

117. See R. Weiss, Marital Separation 263-66 (1975); Pro Se Divorce, supra note 26, at 141-43; cf. Q. Johnstone \& D. Horson, LAWYers AND THEIR WORK 81 (1967) ("'[o]ne of the most common lawyer tasks is negotiation"); Eisenberg, supra note 1, at 661-62 (role of "affiliates," who may be lawyers, in negotiation). 
e. Litigator. When there is a dispute that must go to court, the lawyer has responsibility for marshaling and presenting relevant evidence and making the necessary legal arguments.

\section{Evaluating the Lawyer's Role}

If one accepts the proposition that the primary function of the legal system should be to facilitate private ordering and dispute resolution, then several important questions come into sharp focus. To what extent does the participation of lawyers facilitate dispute resolution? Are there fairer and less costly procedures in which lawyers would play a lesser role?

Many observers are very critical of the way some lawyers behave in divorce negotiations. Lawyers may make negotiations more adversarial and painful, and thereby make it more difficult and costly for the spouses to reach agreement. ${ }^{118}$

Indeed, lawyers may be more likely than lay people to adopt negotiating strategies involving threats and the strategic misrepresentation of their clients' true preferences in the hope of reaching a more favorable settlement for the client. Ivan Illich has suggested that a broad range of illnesses are "iatrogenic": induced and created by medical treatment and the health industry. ${ }^{110}$ The same charge might be made against the legal profession. The participation of lawyers in the divorce process may on balance lead to more disputes and higher costs without improving the fairness of outcomes.

Yet, there are also arguments that lawyers facilitate dispute settlement. Lawyers may make negotiations more rational, minimize the number of disputes, discover outcomes preferable to both parties, increase the opportunities for resolution out of court, and ensure that the outcomes reflect the applicable legal norms. Professor Eisen-

118. See, e.g., R. EIsLeR, Dissolution 40 (1977) ("legal system of battle where two adversaries try to get the 'best possible deal' for their clients only tends to exaggerate, rather than resolve, the emotional tensions of a divorce"); M. VAnton, Marriage-Grounds For Divorce 99-100 (1977) (accusing divorce lawyers of inflaming antagonisms, prolonging negotiations, and doing nothing to attempt to save the marriage-all in order to obtain large fees); cf. Watson, The Lawyer as Counselor, 5 J. FAM. L. 7, 9, 11-20 (1965) (stressing counseling role of lawyer and suggesting that lawyers develop interviewing skills grounded in awareness of dynamics of situation). But see R. FELDER, Drvorce 1-2 (1971) (member of divorce bar defending hired-gun approach: reason for which lawyer is hired is to "do anything and everything ... necessary ... to gain [client] a divorce in which he will come out financially, psychologically-in every way-on top"). A more positive appraisal can be found in M. HuNr, supra note 3, at 219-21, which suggests that, although the legal process is not designed to be a therapeutic mechanism, it generally does have some therapeutic aspects-e.g., some "people purge themselves of crippling feelings by the haggling process," id. at 220.

119. I. ILLICH, MEDICAL NEMESIS 21-25 (1975). 
berg has suggested that a pair of lawyers-each acting for his clientmay make the process of negotiation very much like adjudication, in which "rules, precedents, and reasoned elaboration ... may be expected to determine outcomes." 120 When each disputant is represented, the lawyers

are likely to find themselves allied with each other as well as with the disputants, because of their relative emotional detachment, their interest in resolving the dispute, and, in some cases, their shared professional values. Each ... therefore tends to take on a Janus-like role, facing the other as an advocate of his principal, and facing his principal as an advocate of that which is reasonable in the other's position.

.... Because a lawyer is both a personal advisor and a technical expert, each actor-disputant is likely to accept a settlement his lawyer recommends. ${ }^{121}$

In view of the critical role of lawyers and the disparate functions they may perform, it is startling how little we know about how lawyers actually behave. Obviously, lawyers are not all the same. Their styles and talents differ. Some lawyers are known within the profession as negotiators who strive to find middle ground acceptable to both sides; others are fighters who love the courtroom battle. Research could usefully explore how much specialization there is and, more importantly, the extent to which clients, when they are choosing a lawyer at the time of divorce, have any, notion at all of their lawyers' skills or preferences for these various roles. More generally, systematic empirical research might illustrate how often, and in what circumstances, lawyers facilitate dispute settlement at the time of divorce, and how often, and in what circumstances, they hinder it.

This framework also suggests how timely it is to reexamine the question of why the legal profession should have a monopoly on these roles and the extent to which it does have such a monopoly. How well are lawyers trained to perform these various roles? Other professionals or paraprofessionals might serve some of these functions as well as lawyers at a substantially lower cost. This is most obviously the case when there is no dispute, and the attorney's role is essentially that of a clerk.

A recent study in Connecticut suggests that in most uncontested divorces, clients believe their lawyer has done no more than fill out

120. Eisenberg, supra note 1 , at 638.

121. Id. at 664 (footnotes omitted). 
the necessary forms (a complaint, a claim for a hearing, and a decree) and make an appearance at a pro forma hearing. ${ }^{122}$ Moreover, the same study suggests that because the forms and procedures are complicated, do-it-yourself "divorce dissolution kits" do not, without additional lay assistance, pose much of a threat to the monopoly of the organized bar. ${ }^{123}$ Most people lack the time, confidence, or ability to navigate through the legal shoals themselves, even when they have no dispute with their spouse. This suggests that reform aimed at simplifying the procedures for uncontested divorce could substantially reduce transaction costs in many cases. ${ }^{124}$

\section{Counsel for the Child}

Numerous articles have advocated the appointment of counsel for children. ${ }^{125}$ Most of the literature has focused on the difficulties of role definition for an attorney in court when his client may not be mature enough to define his own interests. ${ }^{126} \mathrm{~A}$ bargaining perspective suggests a somewhat different set of questions: how does the appointment of counsel for the children affect the bargaining process and its outcome? Does an attorney for the children facilitate dispute resolution between the parents or make it more difficult? How are transaction costs affected?

A recent student Note sheds some light on these issues. ${ }^{127}$ Based on interviews with Connecticut attorneys who represented children in custody suits, it suggests that the child's attorney performs an important function as a mediator by helping the parents and their attorneys to define their positions and reach an out-of-court agreement. ${ }^{128}$ Moreover, in negotiating an agreement, a child's attorney

122. Pro Se Divorce, supra note 26, at 154, 156.

123. See id. at 163 .

124. Procedural simplifications could take many forms. An extension of pro se opportunities could be accomplished by a simplification of divorce forms and procedures accompanied by a clear legislative mandate permitting lay assistance without harassment by the organized bar on grounds of unauthorized practice. See id. at 165 . Uncontested divorces could be handled entirely by an administrative agency. The registrar system in Britain seems headed in this direction. See Registrars Study, supra note 16. A less drastic remedy suggested by Professor Geoffrey Hazard, which would reduce the number of lawyers involved rather than eliminate the lawyerly role altogether, would involve a more permissive attitude toward potential conflicts of interest. Hazard would allow a lawyer approached by divorcing spouses to act as "lawyer for the situation" to help them reach a fair settlement, rather than refusing joint representation because of the fear of later charges of conflict of interests. See G. HAZARd, ETHics in the PRAcTice of LAw 58-68 (1978).

125. See Lawyering for the Child, supra note 27, at $1127 \mathrm{n} .7$ (citing sources).

126. See id. at 1166 \& n.194.

127. See id.

128. See id. at 1173-75. 
introduces and focuses discussion on the child's perspective. ${ }^{129}$ This view of the child's representative seems plausible and serves as an important counterargument to fears that introducing an attorney for the child will necessarily increase contentiousness. ${ }^{130}$

But the Note leaves unanswered critical questions concerning costs and generalizability. In the Connecticut cities studied, counsel for the child apparently were appointed in only a small number of disputed cases in which a judge exercised discretion. ${ }^{131}$ These cases represented only a minuscule fraction of the total number of divorces involving children. ${ }^{132}$ Moreover, the Note does not indicate how transaction costs were affected by the appointment of counsel. ${ }^{133}$

Even if one accepts the proposition that in disputed cases that would otherwise require adjudication, counsel for the child facilitates dispute resolution, this does not necessarily mean that this attorney would facilitate the process or be worth the costs in a broader cross-section of cases. Suppose, for example, that counsel for the child were appointed in all cases. ${ }^{134}$ Obviously the additional attorneys' fees might be substantial. Moreover, what would be the effect on negotiations between the parents in cases in which a court is not now called on to resolve any disputed issues? It might well be that counsel for the child could play a useful role in negotiations in some of these cases. But it is certainly possible that in many, the process of negotiation would be made much more complicated and costly, and that the outcomes would not be improved from the child's perspective.

129. See id. at 1174 .

130. See id. at 1172 \& $n .225$ (citing sources).

131. The Note interviewed attorneys who represented children in approximately 35 cases during a three-year period. See id. at 1178 n.250.

132. During the three-year period when counsel for the child was appointed in 35 cases, we estimate there were $8,000-10,000$ divorces involving children in the two Connecticut counties studied. The total number of divorces filed in the Hartford and New Haven Superior Courts in the fiscal year 1977-78 was 7,178. Telephone Interview with Gregory Pac, Statistical Analyst, Office of the Chief Court Administrator, Judicial Department of Connecticut (Mar. 29, 1979). If Connecticut follows the national average, approximately half of those divorces involved minor children.

133. The attorneys interviewed tended to be young and all billed and received less for their representation of children than would be normal for their practices. Lawyering for the Child, supra note 27 , at 1144 n.81. One wonders whether, if attorneys handled more of these cases, they could afford to be so magnanimous. Moreover, it would probably be necessary to bring fees more in line with standard legal practice in order to attract the number of attorneys necessary to handle the increased load of a broader cross-section of custody cases.

134. For a short time, Connecticut required the appointment of an attorney for the child in uncontested cases. This was soon seen to be impractical and counterproductive. See Berdon, A Child's Right to Counsel in a Contested Custody Proceeding Resulting from a Termination of the Marriage, 50 CoNN. B.J. 150, 155 n.19 (1976). Moreover, counsel for the child has been suggested for undisputed cases. See, e.g., Note, A Child's Due Process Right to Counsel in Divorce Custody Proceedings, 27 Hastings L.J. 917, 948 (1976). 
Research relating to negotiations in other contexts suggests that agreement may be more difficult to reach when it involves more than two parties. ${ }^{135}$

A critical policy question concerns the formulation of criteria for deciding when, and whether, the advantages of counsel for the child outweigh the disadvantages. If counsel is only to be appointed in "disputed cases," operational criteria for identifying such cases must be defined. Some cases-e.g., those in which the parents agree from the outset-are clearly undisputed, while others-in which parents have invoked the court's jurisdiction to resolve a custody issue-are clearly disputed. But there may be many cases in which the parents initially disagree, but later reach a negotiated resolution. When, if at all, should counsel for the child be appointed in these cases?136 There is little data to inform this more refined inquiry. Pilot projects involving careful analysis of the consequences and costs of counsel for the child in a broader cross-section of cases might shed useful light on this important policy question.

\section{E. The Role of Courts}

Because divorce has become so widespread in this country, it is probably the most common occasion for ordinary citizens to interact with courts and the legal system. These contacts, to the extent they seem superfluous and unduly unpleasant, may contribute to public cynicism about law and its processes. Consideration of the issue from

135. In general, expansion of the number of parties directly involved in a bargaining relationship increases the difficulty of co-ordination and introduces a variety of problems, stemming primarily from the conflicting interests and interdependencies among the parties involved. . . Typical of the problems that arise when more than two parties are involved in bargaining exchanges are the need for increased time to reach agreements, an increase in the number of both tangible and intangible issues that may arise, accountability to a greater number of salient audiences, and tendencies to form coalitions.

J. Rubin \& B. Brown, The Soclal Psychology of Bargaining and Negotiations 64 (1975). 136. The Connecticut study identified a disturbing aspect of the appointment of counsel for the child. Since appointment there, as in most states, is discretionary, see Lawyering for the Child, supra note 27, at 1127 n.8, 1142 n.74 (citing statutes), requesting the appointment of an attorney for the child becomes part of a party strategy of delay or evasion. The judge often will not appoint an attorney until one of the parties makes a motion, $i d$. at 1185 , the motion will often not be made until late in the litigation, and it will often be made for purely strategic reasons by a party who feels he has nothing to lose by getting another opinion, see id. A clear rule calling for appointment of an attorney in all cases would have the advantage of removing the appointment from the strategic consideration of the parties. It might also enhance the opportunity for the intervening attorney to play a mediator's role, see id. at 1187 , but it could have the possible disadvantages suggested in text. 
our perspective of private ordering highlights the need for general reform and gives specific support to the oft-asserted desirability of removing undisputed divorce cases from court dockets. ${ }^{137}$

Obviously, the state should provide some mechanism for dispute settlement when the parties have not been able to agree. Having courts adjudicate disputed cases is certainly one plausible way to do this, although alternatives are possible. ${ }^{138} \mathrm{~A}$ striking feature of the present system, however, is the requirement that undisputed cases also pass through court. Every state requires a court proceeding as part of the divorce process, with a narrow exception in California. ${ }^{139}$

This requirement is understandable from a historical perspective: it represented a regulatory mechanism to ensure that divorces were only granted in narrowly defined circumstances. Before the no-fault revolution, dispute settlement was not the primary function of divorce proceedings.

The no-fault revolution has now empowered either spouse unilaterally to create the circumstances for divorce. Ironically, however, the shell of the same administrative and regulatory mechanism has been preserved. This regulatory mechanism comes at a high price. The requirement of a judicial proceeding probably imposes significant transaction costs, both public and private. Parties find it necessary to hire a lawyer, even in uncontested cases in which the lawyer's function is basically that of a clerk. An appearance by a lawyer in court takes time, for which the parties are charged. Moreover, a judicial proceeding requires the use of judicial resources as well as the time of the parties themselves. Indeed, undisputed divorce cases

137. See Llewellyn, Behind the Law of Divorce: II, 33 ColuM. L. REv. 249, 286 (1933); Pro Se Divorce, supra note 26, at 165-66; Note, Untying the Knot: The Cause and Patterns of Divorce Reform, 57 CoRnell L. REv. 649, 666.67 (1972).

138. The alternatives include mediation, see Mnookin, supra note 24 , at 287-88, and other less formal means of adjudication, id. at 289; see Coulson, Family Arbitration-An Exercise in Sensitivity, 3 FAM. L.Q. 22 (1969).

139. See CAL. Crv. Code $\$ \S 4550-4556$ (West Supp. 1979). This provision allows summary dissolution in uncontested divorce only if (1) there are no minor children, (2) the marriage is of not more than two years' duration when the petition is filed, (3) neither party owns any real estate, (4) neither party has unpaid debts of more than $\$ 2000$, excluding any car loan, (5) there is no community property (excluding a car) of more than $\$ 5000$, (6) neither spouse has separate property of more than $\$ 5000$, and (7) spousal support is waived. $I d . \$ 4550$. At any time after six months from the filing of the joint petition for summary dissolution, the court may, at the request of either party, enter final judgment dissolving the marriage. $I d$. $\$ 4553$. Because of these severe limitations, only a tiny proportion of divorcing couples in California will qualify for this new summary procedure. Indeed, it would appear that the divorce bar was entirely successful in limiting the procedure to cases in which there would have been no potential in any event for a significant legal fee. 
clog the family law court system and exact a heavy toll on divorcing spouses in the form of delay. ${ }^{140}$

The requirement of a judicial proceeding in undisputed divorce cases could easily be eliminated. Getting married does not require judicial proceedings, so why should getting a divorce? Some countries have eliminated the requirement that undisputed divorces go through court, ${ }^{141}$ and it therefore seems appropriate to examine the possible justifications for the requirement. ${ }^{142}$

\section{Ceremonial Function}

A judicial proceeding may serve a ceremonial function that reconfirms, both for the divorcing parties and the general public, the seriousness with which the state treats marriage and divorce. Rituals are important, and the court proceeding can be seen as a socially imposed divorce ritual. One may, however, ask how well the existing requirement serves the ceremonial function. The marriage ceremony is an important social ritual, but it can be extremely simple, and it does not require lawyers and a judge. Moreover, in most states the parties to a divorce are not usually required to appear in court, but may simply appear through their lawyers. If the ritual were for the benefit of the parties, presumably their presence would be required. Thus, the requirement is more like a civil fine imposed on a divorcing couple-a fine payable not to the treasury but to the divorce bar. ${ }^{143}$

140. An analogous problem from a negotiation perspective is the existence of significant differences in waiting periods according to whether the divorce is consensual or not. These differences may be created by statute, see, e.g., MD. ANN. Code art. 16, $\$ 24$ (Supp. 1978) (party abandoned may be granted divorce after 12 months; either party may obtain divorce after separation for three years), or by problems of court administration and docketing, see note 28 supra (in some jurisdictions, uncontested matters come to court swiftly, but contested cases usually must wait over one year).

141. See Pro Se Divorce, supra note 26, at 166 (registration coupled with waiting period implemented in uncontested divorces in Denmark, Iceland, Japan, Norway, and Sweden).

142. The analysis that follows criticizes only the requirement that uncontested cases be processed through courts. It is not meant to deny the importance of divorce as a legal event in even the simplest and most amicable case. Eliminating the involvement of judges does not necessarily mean eliminating the involvement of one or more lawyers. Divorce severs some legal obligations and creates others-appropriate legal instruments must often be drawn. It would seem advisable for all divorcing couples, even the most amicable, to consult with someone on the legal consequences of divorce. Nevertheless, this does not suggest that judicial involvement is also necessary. After all, most legal obligations we agree to in life do not require a judge's approval.

143. Albert Hirschman has suggested that

[s]pecific institutional barriers to exit can often be justified on the ground that they serve to stimulate voice in deteriorating, yet recuperable organizations which would be prematurely destroyed through free exit. This seems the most valid, though often not directly intended, reason for the complication of divorce procedures and for the expenditure of time, money, and nerves that they necessitate.

A. Hirschman, Exit, Voice, and Loyalty 79 (1970).

The argument that making divorce easier might lead to the termination of salvageable 


\section{Review Ensures Fair Outcomes: Fairness Between the Spouses in Outcomes}

The requirement of judicial approval of postmarital agreements might be justified on the ground that the state has an interest in ensuring that the results of the bargaining process are fair as between the spouses. A judicial proceeding might protect people from their own ignorance and might also be thought to prevent unfair results arising from the unequal bargaining capacity of the spouses. These arguments are sensible in the abstract, but the reality of the current system suggests that they mean very little in practice. Courts typically rubber stamp an agreement reached by the parties. Moreover, there are reasons to doubt the necessity of judicial review of private agreements for the purpose of preventing unfairness. There may well be cases in which one spouse (stereotypically the husband) is highly sophisticated in business matters, while the other spouse is an innocent lamb being led to the slaughter. But married couples more typically have similar educational and cultural backgrounds, and most individuals perceive very well their own financial interests and needs at the time of divorce.

If there remain legitimate fears that many spouses will be taken advantage of through unequal bargaining, and a realistic hope that judicial review of agreements can identify and remedy such cases, then better means should be found to serve such a beneficial function. The problem with the current system is that all cases must pass through the judicial net and that there are no standards or procedural mechanisms specifically designed to bring cases of unequal bargaining to the judge's attention; the sheer quantity of cases that a judge must oversee probably decreases the chances that he can pick out and give appropriate attention to the right cases. A better system would define, within a broad range, the norms that should govern divorce agreements and use those norms to identify for intensive judicial scrutiny the cases falling outside what is ordinarily thought reasonable. Cases settled within the normal range would require no prior review at all.

marriages was often invoked by those who unsuccessfully opposed the no-fault revolution. The use of costly state-imposed procedures to inhibit divorce seems inconsistent with that revolution; it might also offend, at least for the poor, the constitutional requirements of due process. See Boddie v. Connecticut, 401 U.S. 371 (1971). There is, of course, no empirical evidence demonstrating that procedural simplification in uncontested cases would substantially increase the number of "hasty" or "unwise" divorces. If this turned out to be the case, and it was thought desirable to do something about it, then longer waiting periods or even mandatory marriage counseling might be made preconditions of divorce. 


\section{Effects on Out-of-Court Settlements}

It might be thought that the requirement that undisputed cases go to court improves the private-settlement process outside of court. If parties know that they will have to present their agreement to a judge, they may deal with each other in a fairer way and may be more likely to reach an agreement reflecting appropriate social norms. Behavioral scientists have suggested that the presence of an "audience" can affect bargaining. ${ }^{144}$ In out-of-court negotiations, the judge represents both an "actual" and an "abstract" audience. $\mathrm{He}$ is an actual audience because parties know that eventually they may have to explain their agreement to him, and this may mitigate extreme claims. Indeed, the presence of the judiciary may sometimes exert considerable pressure on the parties "to settle their own differences" and thus avoid litigation. The judge, as a symbol of the social interests in the child and various notions of honor, reputation, and history, may represent an abstract audience as well.

It is extremely difficult to evaluate this argument in the specific context of undisputed divorce cases. The knowledge that disputed cases go before a court may be sufficient to bring the "audience" benefits to the process of negotiation. It seems doubtful, however, that the behavior of divorcing spouses in uncontested cases is discernibly affected by the symbolic (as contrasted with actual) presence of the judge during negotiations.

\section{Child Protection}

When a divorcing couple has minor children, the state has an additional interest in child protection. The requirement of court review of private agreements relating to custody and child support might be justified on this ground: it may improve the quality of negotiated agreements from the child's perspective. Some parents might otherwise engage in divorce bargaining on the basis of preferences that narrowly reflect selfish interests, rather than concern for the child. The specter of review might serve as an important reminder to the parents of the social concern for their children, and might somehow constrain selfish behavior. Even a selfish spouse may be more concerned about his reputation as a parent if there is some sort of public process. Thus, in cases involving children, the judge's role as "audience" is especially important. Finally, although most parental agreements are approved after only superficial examination

144. See J. RuBin \& B. BRown, supra note 135, at 43-54. 
by the judge, some agreements may in fact be disapproved. To the extent courts succeed in identifying arrangements that are disadvantageous to a child in a particular case and in imposing some better alternative, judicial scrutiny serves a useful purpose.

The realism of these arguments, though, seems questionable. The evidence we have suggests that in operation courts rarely overturn parental agreements. Given the resources devoted to the task of scrutinizing agreements, ${ }^{145}$ there is little reason to believe that the process operates as much of a safeguard when there is no parental dispute to catch the judge's attention. Moreover, the process itself often imposes substantial transaction costs-both public (in terms of government resources expended) and private (in terms of the cost to the parties, the legal fees, and time). These extra transaction costs might otherwise inure, at least in part, to the benefit of the children.

There are also reasons to think that, in the vast majority of cases, judicial review is unnecessary. The custodial spouse will typically perceive and attempt to influence the economic consequences for the child of any support arrangement that he or she agrees to, since there is considerable joint consumption between the custodial parent and the child. ${ }^{146}$ Moreover, most parents care deeply for their children.

No court proceeding can require parents to love their children, and no judge can prevent selfish calculation by a divorcing parent. The implicit attitude during the heyday of the fault-based system was that there are good reasons not to trust parents with child-rearing decisions following divorce. But is this attitude really appropriate today?

Consider, by comparison, the review requirements imposed by law if the child's family is disrupted by the death of one parent. American law permits a parent to disinherit his minor children. ${ }^{147} \mathrm{~A}$ decedent cannot, however, disinherit his spouse, and current law effectively entrusts the surviving parent with child-rearing responsibility in the light of existing economic resources. There is no ongoing supervision of how a surviving spouse spends the inheritance, and there is no examination of what portion is spent on the child. Instead, the sur-

145. See note 26 supra (study in Connecticut revealed that average of four minutes of court time spent on uncontested divorces).

146. See p. 960 supra.

147. See R. MNookin, supra note 21, at 214-16.

There is, of course, substantial judicial supervision if money or property is left directly to a child: typically there must be a guardian for the child's estate. The law requires substantial constraints on the guardian's power to invest and spend the money, and typically imposes considerable costs. Indeed, it is precisely for these reasons that a primary goal in estate planning is to avoid guardianships, and instead use trusts if property is intended for the benefit of minor children. See id. at 217-19. 
viving parent is trusted to look after the child-subject, of course, to the minimum limitations applicable to all parents of the child neglect laws. The same parental discretion seems appropriate if the household is disrupted by divorce rather than death.

The requirement of judicial review in all divorce cases involving children may, ironically, send inappropriate signals to parents at the time of divorce: it may suggest to them that because of the divorce they are no longer trusted to be adequate parents, and the state will now assume on an ongoing basis special responsibility for their children. Such signals are not only gratuitously insulting, but wrong: the state does not and cannot assume broad child-rearing responsibilities after divorce.

\section{Conclusion}

Viewing the process of divorce from the perspective of private ordering does not make previously intractable family law problems disappear. If anything, the world seems even more complex, since the analysis requires us to examine the effects of alternative rules and procedures on informal and formal bargaining about which we have little understanding. There now exists no bargaining theory that can yield accurate predictions of the expected outcomes with different legal rules, even when rational, self-interested parties are only negotiating over money issues. Divorce bargaining is often considerably more complex.

Given the absence of powerful theory or systematic data, this essay makes no claims to being definitive. It instead suggests a theoretical perspective that permits a broader analysis of the probable consequences of family law rules and procedures. It also more sharply exposes a set of questions of enormous social importance. If one accepts the proposition that the role of the legal system in determining the consequences of divorce should reflect an emphasis on dispute settlement, then the inadequacies of our current system are readily apparent. The analysis does not imply that the state should simply withdraw all resources from the process and leave it to the divorcing spouses to work things out on their own, unassisted by any professional help or legal protection. Instead, this inquiry should emphasize the desirability of learning more about how alternative procedural mechanisms might facilitate dispute resolution during a typically difficult and painful time in the lives of parents and children alike. 


\section{Divorce and Dispute Resolution}

The perspective certainly has implications far broader than family law. Individuals in a wide variety of contexts bargain in the shadow of the law. Few automobile accident claims are ever tried; most are settled out of court. ${ }^{148}$ Criminal prosecutions are typically resolved by a plea bargain. ${ }^{149}$ Most administrative proceedings result in consent agreements rather than trials. ${ }^{150}$ In each of these contexts, the preferences of the parties, the entitlements created by law, transaction costs, attitudes toward risk, and strategic behavior will substantially affect the negotiated outcomes. Indeed, we hope this article will stimulate and encourage further work by others in a variety of contexts. Theoretical and empirical research concerning how people bargain in the shadow of law should provide us with a richer understanding of how the legal system affects behavior, and should allow a more realistic appraisal of the consequences of reform proposals.

148. See H. Ross, SetTled Out of Court 6.9 (1970).

149. See Alschuler, The Prosecutor's Role in Plea Bargaining, 36 U. CHI. L. REv. 50, 50 (1968). For criticism of the plea-bargaining system, see, e.g., Alschuler, The Defense Attorney's Role in Plea Bargaining, 84 YALE L.J. 1179 (1975); Note, The Unconstitutionality of Plea Bargaining, 83 HARv. L. REv. 1387 (1970).

150. See, e.g., G. Robinson \& E. Gellhorn, The Administrative Process 523 (1974) ("'m]ore than three-fourths of all complaints docketed by the FTC have historically resulted in consent settlements"). 